REVIEW

\title{
Dengue viral infections
}

G N Malavige, S Fernando, D J Fernando, S L Seneviratne

Postgrad Med J 2004;80:588-601. doi: 10.1136/pgmj.2004.019638

Dengue viral infections are one of the most important mosquito borne diseases in the world. They may be asymptomatic or may give rise to undifferentiated fever, dengue fever, dengue haemorrhagic fever (DHF), or dengue shock syndrome. Annually, 100 million cases of dengue fever and half a million cases of DHF occur worldwide. Ninety percent of DHF subjects are children less than 15 years of age. At present, dengue is endemic in 112 countries in the world. No vaccine is available for preventing this disease. Early recognition and prompt initiation of appropriate treatment are vital if disease related morbidity and mortality are to be limited. This review outlines aspects of the epidemiology of dengue infections, the dengue virus and its mosquito vector, clinical features and pathogenesis of dengue infections, and the management and control of these infections.

See end of article for authors' affiliations

Correspondence to: Dr Suranjith L Seneviratne, Department of Clinical Immunology, A Floor, West Block, Queens Medical Centre, University Hospital, Nottingham NG7 2UH, UK; suran200@ yahoo.co.uk

Submitted 25 January 2004 Accepted 15 March 2004

\section{EPIDEMIOLOGY}

During the 19th century, dengue was considered a sporadic disease, causing epidemics at long intervals. However, dramatic changes in this pattern have occurred and currently, dengue ranks as the most important mosquito borne viral disease in the world. In the past 50 years, its incidence has increased 30 -fold with significant outbreaks occurring in five of six World Health Organisation (WHO) regions. At present, dengue is endemic in 112 countries in the world. ${ }^{12}$

Around 2.5 to 3 billion people, living mainly in urban areas of tropical and subtropical regions, are estimated to be at risk of acquiring dengue viral infections. ${ }^{2}$ Estimates suggest that annually 100 million cases of dengue fever and half a (DHF) occur in the world with a case fatality in Asian countries of $0.5 \%-3.5 \% .^{3}$ Of those with DHF, $90 \%$ are children less than 15 years of age. ${ }^{2}$

DHF first emerged as a public health problem in 1954, when the first epidemic occurred in Manila. This gradually spread to other countries in the region. Major epidemics occurred in other regions of the world in the 1980s and 1990s and were caused by all four dengue viral serotypes. ${ }^{4}$ While the predominant serotype in the 1980s and the early 1990s was DEN-2, in recent years it has changed to the DEN-3 serotype. ${ }^{56}$ In 1998, a pandemic of dengue viral infections occurred, where 1.2 million cases of dengue fever and DHF were reported from 56 countries worldwide. The world population was exposed to a new subtype million cases of dengue haemorrhagic fever of the DEN-3 virus (subtype III), which originated in the Indian subcontinent and later spread to involve other continents. ${ }^{7}$ Exposure of a non-immune population to this new subtype of DEN-3 may have been the cause of this pandemic. A situation of comparable magnitude was also seen in 2001-02.

Although sporadic dengue fever was known for more than 200 years, reasons for the global resurgence of epidemics of dengue fever and DHF are not very clear. ${ }^{4}$ Uncontrolled population growth, unplanned and uncontrolled urbanisation, inadequate wastewater management, and lack of effective mosquito control have been implicated in the increased distribution and density of the vector and also the increased spread of the virus. ${ }^{8}$ However, microevolution of the dengue virus may have also contributed to the spread of more virulent strains around the world. In fact there is evidence that the more virulent genotypes of the virus are replacing the less virulent genotypes, which may explain the global emergence of dengue infections."

Figure 1 shows the world distribution of the predominant dengue mosquito vector and areas with epidemic dengue activity. During the period 1955-98, the average annual number of cases of dengue fever/DHF reported to the WHO is shown in fig $2 .^{2}$

\section{Epidemiological trends in South East Asia}

The first epidemic of DHF in South East Asia occurred in 1954 in Manila, Philippines. Following this, epidemics have occurred in nearly all countries in this region, and currently are a major public health problem in seven of them. The incidence of DHF has increased dramatically in recent years with approximately five times more cases reported since 1980 than in the previous 30 years. $^{2}$ Although serological surveys conducted in Indonesia showed that DEN-1 and DEN-2 were the prevalent serotypes until the late 1980s, the DEN-3 serotype has been the predominant serotype in the recent outbreaks. ${ }^{10}$ In fact, DEN-3 has been associated with severe dengue epidemics and it has been suggested that the DEN-3 virus may have certain characteristics that make it more virulent. Although DEN-4 has been isolated in almost all epidemics, it is primarily detected in secondary dengue infections. ${ }^{11}$

DHF (with an attack rate in the range 300-440 cases/100 000 population) is a leading cause of

\footnotetext{
Abbreviations: DHF, dengue haemorrhagic fever; ELISA, enzyme linked immunosorbent assay; IFN, interferon; IL, interleukin; NS, non-structural (proteins); sNS, secreted non-structural (proteins); RT-PCR, reverse transcriptasepolymerase chain reaction; TNF, tumour necrosis factor; WHO, World Health Organisation
} 


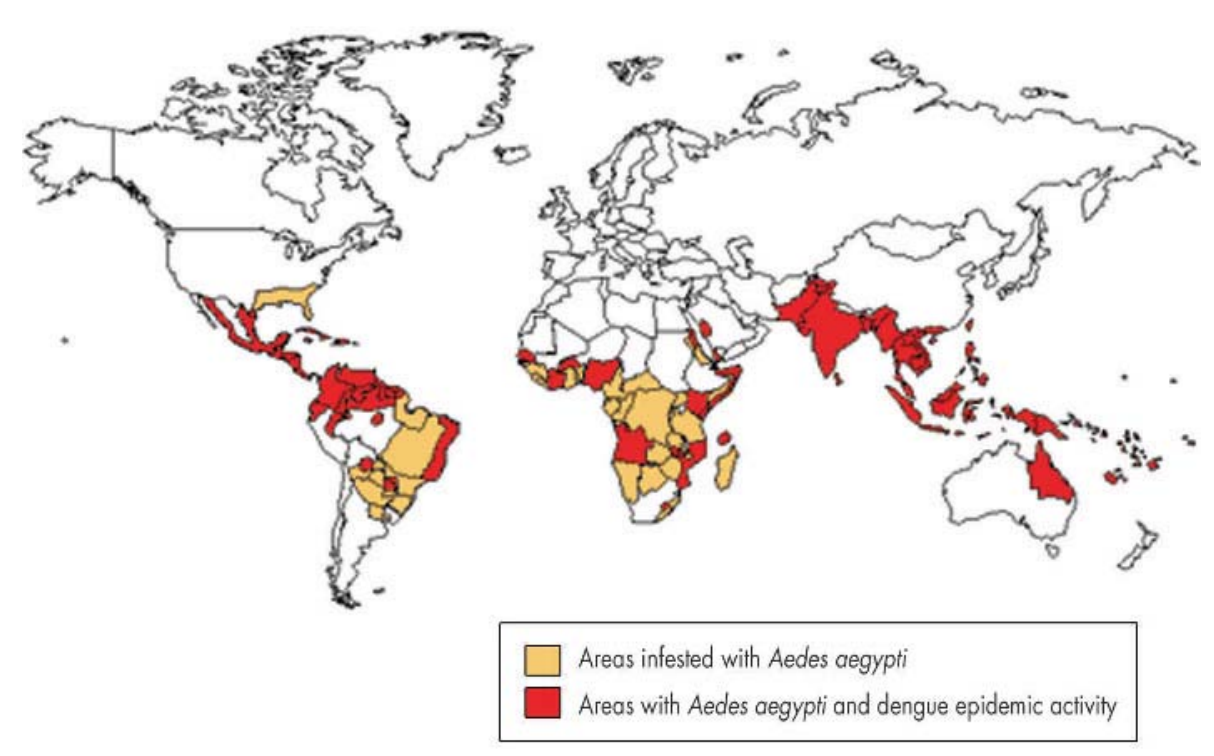

Figure 1 World distribution of the predominant dengue mosquito vector (Aedes aegypti) and areas with dengue epidemic activity.

hospitalisation in children in South East Asia. While this rate has now fallen in Thailand (95-103 cases/100 000 population in 1997), ${ }^{12}$ some countries such as Vietnam, still experience very high attack rates. ${ }^{13}$ Although case fatality rates in most countries in South East Asia have declined and are now less than $1 \%$, those in some countries still exceed $4 \%$, mainly due to late admission to hospital, when the disease is at an advanced state. ${ }^{14}$ In the newly industrialised countries such as Singapore and Malaysia, successful vector control programmes led to a gradual decline in the incidence of dengue, but even here a resurgence has been seen since $1994 .{ }^{14}$

\section{Epidemiological trends in South Asia}

Although small outbreaks of DHF occurred South Asia between 1964 and $1966,{ }^{15}$ the first major epidemic of DHF occurred in Sri Lanka in 1989. Since then regular epidemics have occurred in Sri Lanka, resulting in increasing numbers of cases each year. The DEN-3 subtype III was identified as the cause of the first and subsequent epidemics in Sri Lanka along with the DEN-2 serotype. ${ }^{716}$ Dengue infections were first reported in India in 1991 (6291 cases of dengue fever), and the first epidemic of DHF occurred in Delhi in 1996. ${ }^{17}$ The epidemiological pattern of DHF in South Asia is now similar to that in the South East Asian region. As yet, no cases of DHF have been reported from Nepal or Bhutan. In addition, the endemicity of dengue infections in these two countries is uncertain. $^{2}$

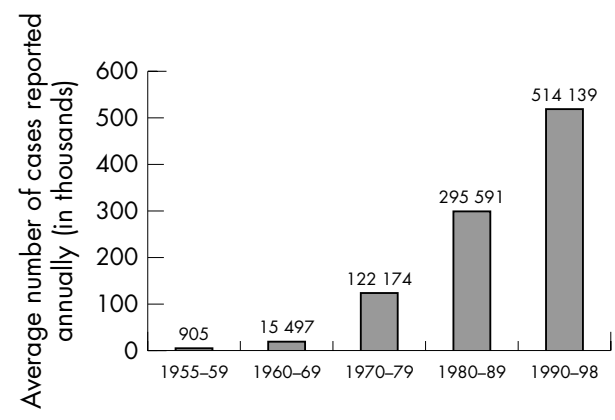

Figure 2 Dengue/DHF, average annual number of cases of reported to the WHO, 1955-98.

\section{Epidemiological trends in the Far East}

In the Far East, epidemics of dengue fever/DHF have been further apart and less severe when compared with those in the South East Asian and South Asian regions. China has been the country most affected. The first epidemic of dengue fever occurred in China in 1978, and was followed by an epidemic of DHF in Hainan Island in 1985-86 (caused by the DEN-2 serotype). ${ }^{18}$ The case fatality rate was $0.25 \%$, which is low compared with that in other regions. ${ }^{19}$ At present, Japan is free of epidemics of dengue fever/DHF, and has previously only been reported before World War II. ${ }^{20}$ Many cases of dengue are still reported from countries such as Australia, Fiji, and New Caledonia. The largest epidemic in recent times occurred in Fiji in 1998 (where 24780 cases were reported). ${ }^{14}$

\section{Epidemiological trends in the Americas}

The first major epidemic of dengue fever occurred in Cuba in 1977-78 (caused by the DEN-1 serotype), followed by the first epidemic of DHF in 1981. This DHF epidemic was also the first in the American region, was caused by DEN-2, with secondary dengue infections accounting for $98 \%-99 \%$ of the cases. After this outbreak a very effective and successful control programme was launched in Cuba resulting in it being free from any dengue viral activity for 16 years (the period 1982-96). ${ }^{21}$

In 1989 an epidemic of DHF occurred in Venezuela, ${ }^{22}$ followed by a further epidemic in Cuba in 1997 (16 years after the first epidemic in this country) both caused by the DEN-2 serotype. Interestingly, no children were affected during the 1997 DHF epidemic. Since viral transmission had been interrupted over a 16 year period, children may have only had a primary infection at the time, hence arguing for the importance of secondary dengue infections in the subsequent development of DHF. ${ }^{21}$

During the last two decades the incidence of dengue fever has increased significantly in this region. In 2002, more than 30 Latin American countries reported over one million cases of dengue fever. DHF occurred in 20 countries with more than 17000 cases reported, including 225 fatalities. ${ }^{23}$ The current epidemiological trend is similar to that seen in Asia, with DHF epidemics occurring every three or four years, with increasing numbers of cases seen with each epidemic. ${ }^{22}$ Interestingly, DHF is absent in Haiti despite there being hyperendemic dengue virus transmission. These observations, which are reminiscent of those seen in Africa, suggest 
the presence of a dengue resistance gene in black populations. ${ }^{24}$

\section{Epidemiological trends in Africa}

Although the mosquito vector and all four dengue viral serotypes are present in the African region, to date an epidemic of DHF has not occurred. ${ }^{4}$ Since DHF is less frequent among black persons living in areas that experience epidemics of DHF, it is possible that individuals of African origin may have a degree of inherent resistance to the disease.

\section{CHARACTERISTICS OF THE DENGUE VIRUS}

The dengue virus is a single stranded RNA virus belonging to the flaviviridae family. ${ }^{8}$ There are four serotypes (DEN l-4), classified according to biological and immunological criteria. The viral genome is approximately $11 \mathrm{~kb}$ in length. ${ }^{8}$ The mature virion consists of three structural (core, membrane associated, and envelope) and seven non-structural (NS1, NS2a, NS2b, NS3, NS4a, NS4b, and NS5) proteins. The envelope protein is involved in the main biological functions of the virus. It binds to receptors on host cells, allowing the virus to be transported through it. In addition, the envelope protein is associated with haemagglutination of erythrocytes, induction of neutralising antibodies and protective immune responses. ${ }^{25}$

Non-structural proteins (NS1-NS5) expressed as both membrane associated and secreted forms have also been implicated in the pathogenesis of severe disease. Unlike other viral glycoproteins, NSI does not form a part of the virion but gets expressed on the surface of infected cells. Preliminary evidence suggests its involvement in viral RNA replication. ${ }^{26}$ Plasma levels of secreted NSI (sNS1) correlate with viral titres, being higher in patients with DHF compared with dengue fever. ${ }^{27}$ Moreover, elevated free sNS1 levels within 72 hours of onset of illness identify patients at risk of developing DHF. Very high levels of NSI protein are detected in acute phase samples from patients with secondary dengue infections but not primary infections. This suggests that NSI may contribute to formation of circulating immune complexes, which are thought to have an important role in the pathogenesis of severe dengue infections. ${ }^{26}$

The dengue virus shares antigenic epitopes with other flaviviruses such as Japanese encephalitis virus. These shared epitopes may lead to production of cross reactive antibodies and hence interfere with serological diagnosis. However, antibodies directed to the prM protein of dengue viruses are species specific (not cross reactive with those of other flaviviruses) and may be useful for seroepidemiological studies in dengue (especially in countries where other flaviviruses are endemic). ${ }^{28}$

\section{MOSQUITO VECTORS IN DENGUE INFECTIONS}

Mosquitoes belonging to the genus aedes (Aedes aegypti, Aedes albopictus, and Aedes polynesiensis) play an important part in transmission of dengue. The primary and most important vector is $A$ aegypti, but $A$ albopictus and $A$ polynesiensis may act as vectors depending on the geographic location. ${ }^{2}$ For instance, $A$ albopictus has been found to sometimes transmit dengue in Thailand, Samui island, India, Singapore, and Mexico.

Aedes aegypti, a container breeding, day biting mosquito is found in tropical and subtropical areas (fig 1). ${ }^{29}$ They rest indoors, mainly in living rooms and bedrooms. This maximises man-vector contact and minimises contact with insecticides sprayed out doors, hence contributing to difficulty in controlling this vector. ${ }^{30}$

Aedes aegypti can breed in polluted water or small collections of water such as flower vases or coconut shells. ${ }^{31}$ Eggs can
Box 1: Differential diagnosis of dengue fever

and DHF

Dengue fever

- Infectious mononucleosis.

- Chickengunya viral infections.

- Coxsackie and other enteroviral infections.

- Rickettsial infections.

- Rubella.

- Parvovirus B19 infections.

- Leptospirosis.

- Influenza.

DHF

- Leptospirosis.

- Chikengunya viral infections.

- Kawasaki disease.

- Yellow fever.

- Hanta viral infections.

- Other viral haemorrhagic fevers.

- Meningococcal septicaemia.

survive for long periods, as they are capable of withstanding desiccation. Improper disposal of garbage or inadequate wastewater drainage facilitates, both consequences of unplanned urbanisation, may be responsible for high mosquito densities in endemic areas.

Significant increases in the mosquito larval populations are seen during the rainy season. This may be a reason why epidemics of dengue tend to coincide with the rainy season. ${ }^{29}$ Furthermore, ambient temperature and relative humidity affect viral propagation in mosquitoes; rates being highest in climates resembling the rainy season. ${ }^{32}$ Environmental temperatures also affect the time to acute viraemia in female mosquitoes, being shorter with rises in temperature. ${ }^{33}$

After biting an infected human, dengue viruses enter an adult female mosquito. The virus first replicates in the midgut, reaches the haemocoel and haemolymph, and then gains access to different tissues of the insect. After viral replication in the salivary glands, the infected mosquito can transmit the virus to another human. Ultrastructural studies show viral particles within the nervous system, salivary glands, foregut, midgut, fat body, epidermal cells, ovary and internal body wall lining cells of the mosquito. In contrast, they are absent from muscle, the hindgut, and malphigian tubules.

Compared with uninfected mosquitoes, infected ones take longer to complete a blood meal. This may contribute to the efficiency of $A$ aegypti as a dengue viral vector. This increased time corresponds to dengue virus infection of organs known to control or influence activities associated with feeding. ${ }^{34}$

Several studies suggest the existence of transovarial dengue virus transmission in aedes infected female mosquitoes, allowing propagation of virus to their progeny. Such a process would allow it to act as a reservoir for virus maintenance during interepidemic periods (without human or other vertebral host participation). ${ }^{35}$ Reports also suggest that dengue viruses may be transmitted sexually from the male to female mosquitoes, but not vice versa. ${ }^{36}$

\section{CLINICAL MANIFESTATIONS OF DENGUE INFECTIONS}

Dengue infections may be asymptomatic or give rise to undifferentiated fever, dengue fever, DHF, or dengue shock 


\section{Box 2: Clinical features of DHF}

\section{General}

- High fever, intermittent.

- Severe headache (especially retro-orbital).

- Flushing.

- Myalgia and arthralgia.

- Vomiting.

- Anorexia.

- Acute abdominal pain.

Bleeding manifestations

- Epistaxis.

- Bleeding from gums.

- Petechiae and eccymoses.

- Haematemesis and maelena.

- Spotting or menorrhagia in females.

Features of plasma leakage

- Circulatory disturbances (low blood pressure, tachycardia, narrow pulse pressure, and poor capillary refill time).

- Periserositis (pleural effusions, ascites sometimes pericarditis).

\section{Complications}

- Encephalopathy and encephalitis.

- Liver failure.

- Myocarditis.

- Disseminated intravascular coagulation leading to massive bleeding.

syndrome. The differential diagnosis of dengue fever and DHF is shown in box 1 .

\section{Undifferentiated fever}

This usually follows a primary infection but may also occur during a secondary infection. Clinically it is indistinguishable from other viral infections.

\section{Dengue fever}

Dengue fever may occur either during primary or secondary infections. The onset is sudden with high fever, severe headache (especially in the retro-orbital area), arthralgia, myalgia, anorexia, abdominal discomfort, and sometimes a macular papular rash. The fever may be biphasic and tends to last for 2-7 days. ${ }^{37} 38$ Flushing, a characteristic feature is commonly observed on the face, neck, and chest. Coryza may also be a prominent symptom especially in infants. ${ }^{39}$ Younger children tend to present with coryza, diarrhoea, rash and seizure, and less commonly with vomiting, headache, and abdominal pain. ${ }^{40}$

Although, haemorrhagic manifestations are uncommon in dengue fever, petechiae/pupura, gastrointestinal bleeding, epistaxis, and gingival bleeding have been observed in some individuals. ${ }^{37}{ }^{41}$ A positive tourniquet test has been reported in many individuals with dengue fever possibly due to reduced capillary fragility. ${ }^{42}{ }^{43}$ Recovery from dengue fever is usually uneventful, but may be prolonged especially in adults. $^{2}$

\section{Dengue haemorrhagic fever}

DHF usually follows secondary dengue infections, but may sometimes follow primary infections, especially in infants. In

\section{Box 3: WHO case definition of DHF}

\section{WHO case definition of DHF}

A patient with the following four criteria:

1. Acute sudden onset of high fever for 2-7 days.

2. Haemorrhagic manifestations with at least a positive tourniquet test.

3. Platelet count $<100 \times 10^{9} /$.

4. Haemoconcentration (rising packed cell volume $>20 \%$ ) or other evidence of plasma leakage-for example, ascites, pleural effusions, low level of serum protein/ albumin.

such infants, maternally acquired dengue antibodies are presumed to enhance primary infections. ${ }^{44}{ }^{45}$ Such a phenomenon has not been described in human infections other than dengue. ${ }^{45}$ DHF is characterised by high fever, haemorrhagic phenomena, and features of circulatory failure (box 2). ${ }^{46} 47$ The WHO case definition of DHF is given in box 3. For purposes of description DHF is divided into three phasesnamely: febrile, leakage, and convalescent phases. Furthermore, according to severity DHF is divided into four grades (box 4).
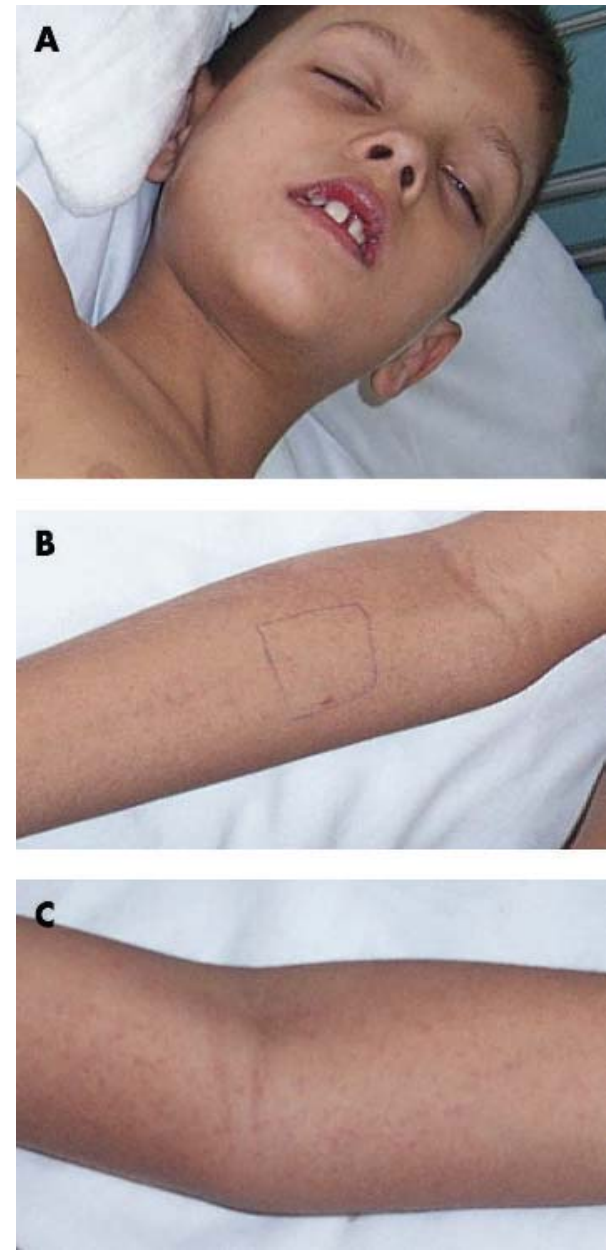

Figure 3 (A) Flushed appearance of face with reddish discoloration of lips; (B) positive Hess's test with surrounding petechiae; (C) characteristic petechial rash on patient's arm (published with permission). 


\section{Box 4: Grading of DHF}

- Grade I: no shock: only positive tourniquet test.

- Grade II: no shock; has spontaneous bleeding other than a positive tourniquet test.

- Grade III: shock.

- Grade IV: profound shock with unmeasurable blood pressure or/and pulse.

The febrile phase begins with sudden onset fever accompanied by generalised constitutional symptoms and facial flush (fig 3). The fever is high grade, intermittent, and associated with rigors. ${ }^{38}$ Epigastric discomfort, myalgia, vomiting, and abdominal pain are common and patients are usually quite miserable. Sore throats and febrile convulsions may be seen, especially among young children. Tender hepatomegaly is observed in almost all patients and splenomegaly may be seen in some. A macular papular rash similar to that seen in dengue fever is also seen in many patients. ${ }^{48-50}$ The fever lasts for 2-7 days and is followed by a fall in temperature to normal or subnormal levels. At this point, the patient may recover or progress to the phase of plasma leakage. Those who remain ill despite their temperature subsiding are more likely to progress to DHF. Clinical deterioration usually occurs during defervescence (often between days 3 and 4$).{ }^{5152}$

Tachycardia and hypotension characterise the onset of plasma leakage. When plasma leakage is severe patients may develop other signs of circulatory disturbance such as prolonged capillary refill time, narrow pulse pressures, and shock. Inadequate treatment of such patients often leads to profound shock. During the phase of plasma leakage (first 24-48 hours after onset of DHF), pleural effusions and ascites are common. Pleural effusions are usually seen on the right side; a right decubitus chest radiograph is best for detecting small effusions. ${ }^{53}$ Abdominal ultrasound scans may demonstrate ascites or a thickened gall bladder wall. ${ }^{54}$ Pericardial effusions may also occur. This latter complication is uncommon, but is associated with high morbidity and mortality.

In DHF, bleeding may occur from any site and does not correlate with the platelet counts. Haemorrhagic manifestations usually occur once the fever has settled. ${ }^{49}$ Minor degrees of bleeding may manifest as gum bleeding and petechiae. The commonest site of haemorrhage is the gastrointestinal tract, which manifests as haematemesis or melaena, followed by epistaxis. ${ }^{475055}$ Vaginal bleeding is commonly reported in females. ${ }^{56}$

Convalescence in DHF is usually short and uneventful. ${ }^{2}$ The return of appetite is a good indicator of recovery from shock. Bradycardia is also seen in this period. If present, a confluent petechial rash with erythema and islands of pallor (usually known as a recovery rash) is characteristic of dengue infections. During the convalescent stage, many patients also complain of severe itching especially on the palms and soles.

\section{Dengue shock syndrome}

Dengue shock syndrome is associated with very high mortality (around 9.3\%, increasing to $47 \%$ in instances of profound shock). ${ }^{57}$ Severe plasma leakage leading to dengue shock syndrome is associated with cold blotchy skin, circumoral cyanosis, and circulatory disturbances. Acute abdominal pain and persisting vomiting are early warning signs of impeding shock. ${ }^{51}$ Sudden hypotension may indicate the onset of profound shock. ${ }^{58}$ Prolonged shock is often accompanied by metabolic acidosis, which may precipitate disseminated intravascular coagulation or enhance ongoing disseminated intravascular coagulation, which in turn could lead to massive haemorrhage. Dengue shock syndrome may be accompanied by encephalopathy due to metabolic or electrolyte disturbances.

\section{Laboratory findings}

In most cases of dengue fever, platelet counts and serum biochemistry are normal. However, leucopenia, thrombocytopenia, and raised liver enzymes may be seen. In contrast, DHF is always accompanied by a platelet count $<100 \times 10^{9} /$, haemoconcentration (a rise in the packed cell volume $>20 \%$ of basal levels), leucopenia, and raised liver enzymes (box 5). Elevation of both alanine and aspartate aminotransferase levels occur with plasma aspartate aminotransferase levels being higher in children who develop DHF than in those with dengue fever. ${ }^{59}$

A leucopenia of $5 \times 10^{9} / 1$ has been suggested to predict the onset of DHF. ${ }^{43}$ Initial leucopenia is followed by a relative lymphocytosis (with more than 15\% atypical lymphocytes) towards the end of the febrile phase. Abnormal coagulation profiles (prolonged partial thromboplastin time and prothrombin time, raised fibrinogen degradation products), hypoalbuminaemia, and reduced serum complement levels are also seen. These coagulation abnormalities suggest that there is activation of both coagulation and fibrinolysis during acute infection and the degree of activation being greater in severe DHF and dengue shock syndrome. ${ }^{60}$

During prolonged shock, metabolic acidosis, hyponatraemia, and increased blood urea are frequently seen. Plasma lipid concentrations (cholesterol, high and low density lipoprotein) are reduced in patients with more severe forms of DHF; the levels are significantly lower in patients with grade III or IV DHF compared with mild DHF or healthy controls. ${ }^{61}$

\section{Complications of DHF}

Severe dengue infections may give rise to many complications such as liver failure, disseminated intravascular coagulation, encephalopathy, myocarditis, acute renal failure, and haemolytic uraemic syndrome. ${ }^{2}$ Although these complications are generally rare, in recent years they have been reported with increased frequency. ${ }^{62}$ Whether this is a true rise or due to an increase in the total number of cases of DHF needs to be determined.

\section{Liver failure}

Since hepatocytes and Kupffer cells support viral replication, liver involvement is common in all forms of dengue

\section{Box 5 : Laboratory findings in DHF}

Haematological investigations

- Low platelet counts of $<100 \times 10^{9} /$.

- Leucopenia early in the illness.

- Atypical lymphocytosis (>15\%).

- Abnormal coagulation profile (prolonged activated partial thromboplastin time, prothrombin time, raised fibrinogen degradation products).

- Reduced serum complement levels.

Biochemical investigations

- Low albumin levels.

- Electrolyte disturbances.

- Elevated liver enzymes.

- Acidosis. 
infection. ${ }^{63}$ Its severity varies with the overall severity of the dengue infection. Levels of aspartate transaminase and alanine transaminase are significantly higher, and globulins significantly lower among patients with the more severe grades of DHF. ${ }^{62}{ }^{64}$ Infection with DEN-3 or DEN-4 serotypes produce greater liver involvement (liver enzymes higher compared with infection with the other two serotypes). ${ }^{65}$ Fulminant liver failure can occur due to hepatitis or focal necrosis of the liver causing hepatic encephalopathy and even death. ${ }^{66}$

Liver failure usually presents with convulsions or a change in the level of consciousness. Jaundice may be present. Neurological examination may show hyper-reflexia or an extensor plantar response. Electrolyte abnormalities and hypoglycaemia may accompany liver enzyme abnormalities.

\section{Encephalopathy}

Encephalopathy has been reported in $0.5 \%$ of patients with DHF, and has a mortality rate of $22 \%{ }^{67}$ Many factors contribute towards development of encephalopathy including: hepatic dysfunction, electrolyte imbalances, cerebral oedema (caused by vascular changes leading to fluid extravasation), hypoperfusion (due to circulatory disturbances), and dengue encephalitis. ${ }^{68}$ The dengue virus has been isolated from the cerebrospinal fluid of some patients having features of encephalitis. ${ }^{68}$ Furthermore, in mice, breakdown of the blood-brain barrier and direct viral infection of the brain has been shown to occur. There is suggestion that histamine might have a critical role in this process. ${ }^{69}$ Other neurological manifestations such as altered consciousness, seizures, spasticity of limbs, hemiplegia, and a positive Kernig's sign have also been reported in $5.4 \%$ of patients with dengue. ${ }^{2}$

\section{Myocarditis}

Acute reversible myocarditis has been reported in patients with dengue infections. ST segment and T wave changes in the electrocardiogram together with low ejection fractions and global hypokinesia on radionuclide ventriculography have been found. No myocardial necrosis was detected in any of the patients. ${ }^{70}$ In another study, $16.7 \%$ of children had left ventricular dysfunction when assessed by two dimensional and colour Doppler echocardiography. ${ }^{71}$ The left ventricular failure may contribute to hypotension seen in DHF/dengue shock syndrome and may have implications in fluid management as fluid overload may worsen the condition. ${ }^{70}{ }^{71}$

\section{PATHOGENESIS OF DENGUE FEVER/DHF}

Dengue may be caused by any of the dengue viral serotypes. Generally, infection with one serotype confers future protective immunity against that particular serotype but not against other serotypes. Furthermore, when infected for a second time with a different serotype, a more severe infection may occur. This is due to a phenomenon referred to as antibody dependent enhancement, where antibodies against the first serotype enhance infection with the second serotype. However, as only $2 \%-4 \%$ of individuals with a secondary dengue infection develop severe disease, antibody dependent enhancement alone cannot wholly explain this process. ${ }^{8}$ At present, reasons as to why only some individuals develop symptomatic infection are not known, but active research is being pursued by several groups to clarify such mechanisms.

After the bite of an infected mosquito, the dengue virus enters the body and replicates within cells of the mononuclear phagocyte lineage (macrophages, monocytes, and B cells). Additionally, infection of mast cells, dendritic cells, and endothelial cells are known to occur. ${ }^{72-74}$ The incubation period of dengue infections is 7-10 days. A viraemic phase follows where the patient becomes febrile and infective. Thereafter, the patient may either recover or progress to the leakage phase, leading to DHF and/or dengue shock syndrome. Peak plasma viraemia correlates with the severity of dengue infections. ${ }^{75}$ Differences in antibody, cytokine, and T-cell responses are seen among patients with uncomplicated dengue fever or DHF/dengue shock syndrome. For clarity of description, these will be described separately under the headings antibody responses, cytokine responses, and cellular responses to the dengue virus.

\section{Antibody responses to the dengue virus}

Antibody dependent enhancement is thought to play a key part in the pathogenesis of severe dengue infections. During secondary dengue infections, antibodies already present in the patient form complexes with the dengue virus. The Fc portion of these antibodies can then bind to Fc $\gamma$ RI and Fc $\gamma$ RII bearing cells and result in an increased number of cells being infected by the dengue virus. ${ }^{76}$ Antibody dependent enhancement is found to occur only in the presence of subneutralising concentrations of dengue antibodies. ${ }^{77}$ DEN-1 immune sera at 1:250 dilution (subneutralising titre), but not at 1:10 dilution, enhances DEN-2 infection of mononuclear leucocytes, in turn resulting in increased lymphocyte proliferation and decreased interferon- $\gamma($ IFN- $\gamma)$ production. ${ }^{78}$

After primary dengue infection, antibodies form against both structural and non-structural viral proteins. Although, the precise role of these different antibodies are not known, antibodies against viral NS1 have been shown to induce endothelial cell apoptosis in a caspase dependent manner. ${ }^{79}$

After binding with antigen, different IgG subclasses vary in their capacity to activate the classical complement pathway; $I g G_{1}$ being very effective whereas $\operatorname{Ig}_{2}$ being less so. Higher levels of dengue virus specific IgG $\mathrm{Ig}_{1}$ and $\mathrm{IgG}_{4}$ and lower levels of $\mathrm{IgG}_{2}$ are seen in patients with DHF and dengue shock syndrome compared with those with dengue fever. ${ }^{80}{ }^{81}$ Since complement activation could contribute to increased vascular permeability and abnormalities in coagulation the predominating dengue specific IgG subclass may be important in the pathogenesis of severe disease. ${ }^{82}$

There is recent interest in the role of $\operatorname{IgE}$ antibodies in disease pathogenesis. Total and dengue specific IgE antibody levels are higher in patients with DHF and dengue shock syndrome compared with those with dengue fever. ${ }^{82}$ Moreover, total IgE levels are significantly higher in those previously exposed to dengue infections. ${ }^{83}$ During severe dengue infection some studies suggest there are suppressed Thl responses whereas others report predominant Th2 responses. ${ }^{84}$

Varying degrees of thrombocytopenia are common in DHF. Some of the mechanisms responsible for this include: IgM type of antiplatelet antibodies, dengue viral specific antibodies, bone marrow hypocellularity (leading to increases in defective megakaryocytes), or destruction of platelets in the liver and spleen. $^{85}$ Antiplatelet antibodies cause lysis of platelets in the presence of complement. They are found in higher concentrations in patients with DHF/dengue shock syndrome compared with dengue fever, which probably accounts for the greater degree of thrombocytopenia seen in DHF. ${ }^{86}$ The DEN-2 serotype binds to human platelets only in the presence of virus specific antibody, supporting a role for immune mediated clearance of platelets. ${ }^{87}$

Dengue infections are characterised by an increased number of atypical lymphocytes. In addition, an increase in numbers of B-cells and a decrease in numbers of T-cells (most likely due to serum anti-T-cell antibodies) has been reported in DHF. These changes are most pronounced on the day of subsistence of fever or development of shock. ${ }^{88}$ Anti-Bcell antibodies are also found in patients with DHF. These could potentially modulate humoral immune responses during infection. ${ }^{89}$ 


\section{Cytokine responses in dengue infections}

Dengue virus infected monocytes, B-lymphocytes, and mast cells produce different cytokines. At present there is disagreement about the predominant cytokines produced during dengue fever and DHF.

According to Chaturvedi et al serum concentrations of tumour necrosis factor- $\alpha$ (TNF- $\alpha$ ), interleukin (IL)-2, IL-6, and IFN- $\gamma$ are highest in the first three days of illness whereas IL-10, IL-5, and IL-4 tend to appear later. ${ }^{84}$ IL-2 and IFN- $\gamma$ are Th1 and IL-5 and IL-4 Th2 type cytokines. Thus, it has been suggested that Thl responses are seen during the first 3 days and Th2 responses occur later. ${ }^{84}$ Increased levels of IL-13 and IL-18 have also been reported during severe dengue infections, with highest levels seen in patients with grade IV DHF. Serum IL-12 levels are highest in patients with dengue fever, but undetectable in patients with grade III and IV DHF. Levels of transformimg growth factor- $\beta$ (an inhibitor of Th1 and enhancer of Th2 type cytokines) correlate with severity of disease and show an inverse relationship with IL12 levels. ${ }^{90}$ These reports suggest that predominant Th2 responses occur in DHF/dengue shock syndrome, whereas Thl responses seem to protect against severe infections.

DHF patients have higher levels of TNF- $\alpha$, IL-6, IL-13, IL18 , and cytotoxic factor compared with DF patients. These cytokines have been implicated in causing increased vascular permeability and shock during dengue infections. ${ }^{90-92}$ Moreover, cytotoxic factor, produced by CD4+ T-cells, induces macrophages to produce the proinflammatory cytokines IL$1 \alpha$, TNF- $\alpha$, and IL-8. Levels of cytotoxic factor correlate with disease severity (being highest in patients with grade IV DHF). In addition, cytotoxic factor autoantibodies protect against severe disease; highest levels being detected in patients with mild disease. ${ }^{93}$

Serum IL-6 concentrations are higher in patients with DHF and dengue shock syndrome. ${ }^{94}$ IL-6 is produced mainly by mast cells and endothelial cells. ${ }^{66}{ }^{68}$ It is an endogenous pyrogen that also increases endothelial cell permeability. Endothelial cells also produced IL- $8,{ }^{74}$ having potent proinflammatory and chemoattractant activity. Levels of IL- 8 are higher during severe dengue infections and highest in those who died. Activated neutrophils release proteinases such as elastase, which may facilitate neutrophil mediated endothelial injury, and activate the complement, coagulation, and fibrinolytic systems. Since increased serum IL- 8 and elastase are found in patients with severe infections, they may have an important role in pathogenesis of dengue infections. ${ }^{95} 96$

Dengue virus infected lymphocytes produce both IFN- $\alpha$ and IFN- $\gamma^{97}$; levels of the former being higher than the latter. IFN- $\alpha$ inhibits infection of monocytes by the dengue virus and hence is important in controlling primary dengue infections. ${ }^{98}$ Although levels of IFN- $\alpha$ are higher in DHF than dengue fever, no differences in levels are seen among the different grades of DHF. ${ }^{99}$ No differences in levels of IFN$\gamma$ are seen between dengue fever or DHF patients. IFN- $\gamma$ is produced early in the course of infection. Peak levels occur on or before the day of deferverscence and coincide with disappearance of viraemia. ${ }^{100}$

Dengue virus infected dendritic cells produce high levels of TNF- $\alpha$ and IFN- $\alpha$, but low levels of IL-12. Low IL-12 levels in DHF are probably due to failure of its induction by IFN- $\gamma \cdot{ }^{101}$ Reports suggest that IFN- $\gamma$ up-regulates Fc gamma receptors on monocytes and hence augment dengue viral infection. ${ }^{102}$ TNF- $\alpha$ prolongs dendritic cell survival by up-regulating antiapoptotic factors within it. Prolonged survival of dengue virus infected dendritic cells may contribute towards producing severe dengue infections. ${ }^{103}$

Serum concentrations of serum TNF- $\alpha$, IFN- $\gamma$, IL-10, and soluble TNF receptor (sTNF-R p75) are significantly higher in patients compared with normal controls. Increased levels of
TNF- $\alpha$ and IL-10 correlate with haemorrhagic manifestations and platelet decay respectively. IL-10 may also down-regulate platelet function and thus contribute to platelet defects associated with dengue infections. ${ }^{104}$

\section{Cellular immune responses in dengue infections}

Recently, there has been greater focus on studying aspects of cell mediated immune responses in the pathogenesis of DHF. The dengue virus can infect both CD4+ and CD8+ T-cells. ${ }^{105}$ Following primary infection, both serotype specific and serotype cross reactive memory T-cells are formed. Serotype cross reactive responses against DEN-2 tend to be stronger than towards other serotypes. ${ }^{106}$ On secondary exposure to the virus, most serotype cross reactive CD4+ and CD8+ T-cells augment infection by producing various cytokines. ${ }^{107}$ Immunisation studies have been done on healthy volunteers using monovalent vaccines of all four serotypes. After immunisation with one serotype, CD8+ T-cell responses are directed against a variety of viral proteins, with all donors recognising either the NS3 or NS1.2a protein. ${ }^{108}$ Since viral NS3 has multiple epitopes, most T-cells show cross reactivity to these epitopes. ${ }^{109}$

In response to dengue viral antigens, $\mathrm{CD} 4+\mathrm{T}$-cells produce IFN- $\gamma$, TNF- $\alpha$, and TNF- $\beta$ which may contribute to the pathogenesis of secondary dengue infections. ${ }^{110}$ Moreover, CD4+ T-cells from patients with previous primary dengue infections proliferate and produce IFN- $\gamma$ after stimulation with a dengue antigen. As mentioned earlier, IFN- $\gamma$ augments dengue virus infection of human monocytes by up-regulating Fc gamma receptors on them. ${ }^{111}$ Liver injury during dengue infections could also be due to T-cell immune responses as studies suggest that $\mathrm{CD} 4+\mathrm{T}$-cell clones are capable of destroying non-antigen presenting target cells such as hepatocytes.

Dengue infections are associated with decreased numbers of CD4+ T-cells, CD8+ T-cells, and natural killer cells. These levels are lowest on the day of subsidence of fever or development of shock, and tend to increase thereafter. B-cell numbers tend not to be affected. ${ }^{112}$ Generalised bone marrow suppression known to occur in dengue infections may also contribute to the absolute lymphopenia. ${ }^{113}$ Reversal of CD4: CD8 ratios tends to occur around the sixth to 10th day after the onset of fever, being seen more frequently in patients with DHF. ${ }^{114}$

DHF patients have increased serum concentrations of IFN- $\gamma$, soluble CD4, and soluble IL-2R during the period of viraemia, followed later by an increase in soluble CD8. ${ }^{115}$ Levels of IFN- $\gamma$ and sIL-2R decline thereafter. ${ }^{116}$ This suggests that activation of T-cells may be important in controlling acute dengue virus infections.

Studies also suggest that suppression of T-cell responses can occur in dengue fever and DHF. This could persist for at least two weeks after the onset of fever. ${ }^{117}$ In one study, respiratory tract infections or diarrhoea were seen in $6 \%$ of patients after dengue infections. ${ }^{53}$ This suppression has been suggested to be due to a primary defect within antigen presenting cells. IL-10, whose levels are increased in DHF, is known to down-regulate antigen presenting cell responses and induce unresponsiveness in T-cells. Similar patterns of suppression are known to follow many viral infections such as measles and infectious mononucleosis, with its attendant increased risk of secondary infections.

\section{Risk factors for the development of DHF}

Several risk factors have been proposed for development of DHF. These include: serotype and virulence of the infecting dengue virus, ${ }^{118}$ age, sex, immune status, and genetic background of the host. ${ }^{2}$ Case fatality and hospitalisation rates due to DHF/dengue shock syndrome are highest in infants and the elderly. For instance, following a secondary DEN-2 
infection, the risk of death in children is nearly 15 -fold higher than that in an adult. ${ }^{119}$ DHF is also reported to be more severe among females. ${ }^{120}$

Generally malnutrition predisposes to many infectious diseases (for example, measles or tuberculosis) and tends to correlate positively with severity of disease. However, malnutrition appears to be significantly uncommon among patients with DHF, compared with patients with other infectious diseases or healthy children. ${ }^{121}$

DHF tends to be commoner among patients suffering from other chronic illnesses (for example, diabetes mellitus or bronchial asthma). ${ }^{122-124}$ The DEN-2 virus is capable of replicating better within peripheral blood mononuclear cells from asthmatics than non-asthmatics. ${ }^{124}$ Further investigation of these different factors should help us better understand the pathogenesis of DHF and may in turn allow us to identify possible therapeutic options.

\section{HOST GENETIC INFLUENCES IN DENGUE VIRAL INFECTIONS}

Severe dengue infections are seen in only a minority $(2 \%-4 \%)$ of patients with secondary dengue infections. ${ }^{8}$ Human genetic factors have been little studied in DHF, but the small proportion of antibody positive persons who develop DHF, a possible racial difference in susceptibility, and a few studies suggesting HLA associations provide support for some genetic component to variable susceptibility. For instance, in Haiti, despite hyperendemic transmission of dengue fever, DHF is not reported. ${ }^{125}$ Furthermore, in Africa, where all four dengue viral serotypes circulate and epidemics of dengue fever occur, few cases of DHF are seen. ${ }^{4}$

A few studies have looked at the effect of polymorphisms at the major histocompatibility complex locus on susceptibility to DHF. Loke et al carried out molecular HLA typing of patients with DHF in Vietnam. ${ }^{126}$ They found that polymorphism at the HLA class I loci was significantly associated with DHF disease susceptibility, but polymorphism in the HLA-DRBI or TNF genes were not. Furthermore, this association was confined to the HLA-A region and not the HLA-B gene. Children with HLA-A*33 were less likely and those with HLA-A*24 more likely to develop DHF.

Another study suggested HLA-A*0203 to be associated with less severe dengue, regardless of the secondary infecting virus serotype. Furthermore, HLA-A*0207 was associated with DHF in patients having secondary DEN-1 or DEN-2 infections only. This study also suggested HLA-B*51 to be associated with development of DHF in patients with secondary infections, and HLA-B ${ }^{*} 52$ to be associated with dengue fever in patients with secondary DEN-1 and DEN-2 infections. Moreover, after secondary dengue infections HLA-B44, B62, B76, and B77 appeared to protect against development of clinical disease. ${ }^{127}$

Susceptibility to DHF and polymorphisms within five nonHLA candidate genes (IL-4, IL-1RA, MBL, VDR, Fc $\gamma$ RII) have also been studied. ${ }^{128}$ IL-4 and IL-1RA gene variants were not associated with altered risk, and MBL variation did not affect the risk significantly. The vitamin D receptor mediates the immunoregulatory effects of 1,25 dihydroxyvitamin D3 (1,25D3), which include activating monocytes, stimulating cellular immune responses, and suppressing immunoglobulin production and lymphocyte proliferation. Loke et al found the less frequent $t$ allele of a dimorphism at position 352 of the vitamin $\mathrm{D}$ receptor gene to be associated with dengue disease severity. There is a suggestion that the tt genotype may be associated with a relatively stronger Thl type cellular immune response than the TT genotype. By extension it might be inferred that the association of the $t$ allele with resistance to severe dengue might reflect a protective role for enhanced cellular immunity in the disease. ${ }^{128}$
The Fc $\gamma$ receptor II (Fc $\gamma$ RII) is a widely distributed receptor for all subclasses of $\operatorname{IgG}$, and is able to mediate antibody dependent enhancement in vitro by binding to virus IgG complexes. An arginine $(\mathrm{R})$ to histidine $(\mathrm{H})$ substitution at position 131 of the Fc $\gamma$ RIIA gene increases IgG binding affinity of the receptor. Furthermore, the arginine variant is causally associated with reduced opsonisation of $\mathrm{IgG}_{2}$ antibodies. A protective effect of homozygosity for the arginine variant at amino acid position 131 of the Fc $\gamma$ RII against DHF has been suggested.

The availability of an increasing number of defined polymorphisms throughout the human genome will greatly increase the potential power of genetic susceptibility studies in dengue and should provide further insights into possible mechanisms of pathogenesis and protection.

\section{LABORATORY DIAGNOSIS OF DENGUE INFECTIONS}

Methods used for diagnosis of dengue infections include: virus isolation, serology, and molecular techniques such as reverse transcriptase-polymerase chain reaction (RT-PCR) (box 6). However, clinicians tend to treat patients suspected of having DHF before the results from these tests are available.

\section{Virus isolation}

During the febrile phase, dengue viruses can be isolated from serum, plasma, or leucocytes. It can also be isolated from postmortem specimens such as liver, lung, spleen, lymph nodes, thymus, cerebrospinal fluid, or pleural/ascitic fluid. ${ }^{2}$ Ideally, blood should be collected during the febrile period, preferably before the fifth day of illness (that is, before formation of neutralising antibodies). Formation of immune complexes due to the presence of large quantities of neutralising antibodies in secondary dengue patients may interfere with virus isolation. For short periods of time (less than 24 hours) serum can be kept at $4-8^{\circ} \mathrm{C}$, but for longer periods should be stored at $-70^{\circ} \mathrm{C} .^{25}$

Traditionally dengue virus isolation was carried out in newborn mice or cell cultures (Vero cell lines or baby hamster kidney cell lines). However, mosquito cell lines have replaced these methods as they are more sensitive, relatively easy to maintain at room temperature, and can be kept for at least 14 days without change of medium. Currently, inoculation of C636 mosquito cell lines (obtained from $A$ albopictus) is the method of choice. ${ }^{25}$ Virus isolation is done for research purposes only as it needs expertise, takes two weeks to read

Box 6: Laboratory diagnosis of dengue infections

Virus isolation

- Mosquito cell lines.

- Mosquito inoculation technique.

- Vertebral cell culture.

Serological diagnosis

- Haemagglutination inhibition test.

- ELISA.

- Complement fixation test.

- Neutralisation test.

- Antigen capture enzyme immunosorbent assay.

Molecular diagnostic methods

- RT-PCR. 
the results, and is expensive. Since mosquito inoculation techniques are more sensitive than mosquito cell lines for virus isolation, they are the methods of choice for important specimens. ${ }^{25} \mathrm{~A}$ albopictus or Toxorhynchites splendens mosquitoes are used for the inoculation techniques. Immunofluorescence (using serotype specific monoclonal antibodies) or the plaque reduction neutralising test identifies the virus. The immunofluorescence assay is cheaper and provides results faster (2448 hours). ${ }^{129}$

\section{Serological diagnosis}

Methods used for serological diagnosis of dengue infections include: haemagglutination inhibition tests, enzyme linked immunosorbent assay (ELISA), complement fixation test and neutralisation tests. Dengue specific IgM and IgG ELISA is widely used, as it is relatively inexpensive, has good sensitivity, and is quick and simple to perform..$^{25}$ Most patients have measurable IgM antibodies by the fifth day of infection. On average, they become undetectable 30-60 days after the onset of illness. The sensitivity of IgM ELISAs range from $83.9 \%-98.4 \%$ with a specificity of $100 \% .{ }^{124}$ The range of sensitivities may be important in patients with secondary dengue where IgM antibody titres are low. ${ }^{130}$ Antigen capture ELISAs have also been developed. The serotype of the infecting virus can also be identified using conventional or capture ELISAs. ${ }^{131} 132$

The ability of dengue viruses to agglutinate goose erythrocytes is used in the haemagglutination inhibition test. A fourfold or greater rise in antibody titres is suggestive of a flavivirus infection (and not diagnostic of dengue infections). However, a single antibody titre $\geqslant 1 / 2560$ is accepted as indicating secondary dengue infection if supported by a clinical history suggestive of dengue.

\section{Molecular detection}

The sensitivity, specificity, and rapid detection of minute quantities of dengue viral material in the patient's serum makes RT-PCR useful for the detection of dengue infection early in the disease when antibodies are not detected. ${ }^{133}$ RTPCR is more sensitive than virus isolation, allows for rapid detection of dengue infections (results are usually available in 24 hours) and easier identification of the circulating serotype. ${ }^{134}$ It is useful for epidemiological studies as dengue serotypes could be identified without cross reactivity with other flaviviruses.

RT-PCR could also be used for detecting dengue viruses in infected mosquito cell culture supernatants or mosquito larvae. The PCR techniques have also been able to detect dual viraemia in some patients from naturally acquired DEN-1 and DEN-3 infections. The downside of molecular techniques is its relatively high cost and the expertise needed.

\section{MANAGEMENT OF DENGUE INFECTIONS}

Management of dengue infections is mainly symptomatic, as there are no specific drugs effective against the dengue virus. Proper maintenance of fluid balance is a cornerstone in management (table 1). Early identification of the leakage phase with prompt resuscitation helps to reduce complications and improve outcome. Mortality rates have been low in patients admitted early to hospital before the onset of shock. ${ }^{135}$

\section{Management of dengue fever}

Both dengue fever and the febrile phase of DHF are managed similarly. Paracetamol is the only antipyretic recommended for use, since other non-steroidal anti-inflamatory drugs such as aspirin or diclofenac sodium may result in gastric irritation or provoke gastrointestinal bleeding. The recommended dose of paracetamol $(60 \mathrm{mg} / \mathrm{kg} /$ day $)$ should not be exceeded, as otherwise liver injury that accompanies dengue viral

\section{Table 1 Management of dengue infections}

\begin{tabular}{|c|c|}
\hline \multicolumn{2}{|l|}{ Dengue fever } \\
\hline Temperature control & $\begin{array}{l}\text { Paracetamol ( } 60 \mathrm{mg} / \mathrm{kg} / \text { day), tepid } \\
\text { sponging }\end{array}$ \\
\hline \multicolumn{2}{|r|}{ 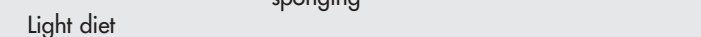 } \\
\hline Monitor & $\begin{array}{l}\text { For progression to DHF by monitoring } \\
\text { platelet count and packed cell volume }\end{array}$ \\
\hline \multicolumn{2}{|l|}{ Grade I and II DHF } \\
\hline Intravenous fluids & $\begin{array}{l}\text { Hartmann's solution, } 5 \% \text { dextrose in normal } \\
\text { saline }\end{array}$ \\
\hline Electrolytes & $\begin{array}{l}\text { Monitor electrolytes in those with altered level } \\
\text { of consciousness }\end{array}$ \\
\hline Temperature control & $\begin{array}{l}\text { Paracetamol }(60 \mathrm{mg} / \mathrm{kg} / \text { day }) \text {, tepid } \\
\text { sponging }\end{array}$ \\
\hline Monitor & $\begin{array}{l}\text { Vital signs, urine output, and level of } \\
\text { consciousness, packed cell volume, and } \\
\text { platelet counts, liver enzymes }\end{array}$ \\
\hline Observe & $\begin{array}{l}\text { Haemorrhagic manifestations: petechiae, } \\
\text { signs of gastrointestinal tract bleeding }\end{array}$ \\
\hline Stop fluids & $\begin{array}{l}\text { When patient recovers from the leakage } \\
\text { phase }\end{array}$ \\
\hline \multicolumn{2}{|l|}{$\begin{array}{l}\text { Grade III and IV DHF and } \\
\text { dengue shock syndrome }\end{array}$} \\
\hline Intravenous fluids & $\begin{array}{l}\text { Crystalloids (Hartmann's solution, } 5 \% \\
\text { dextrose in normal saline) and colloids } \\
\text { (dextran } 40 \text {, fresh frozen plasma, or } \\
\text { gelafundin) several intravenous boluses may } \\
\text { be needed }\end{array}$ \\
\hline Monitor & $\begin{array}{l}\text { Vital signs, urine output, and level of } \\
\text { consciousness, packed cell volume, and } \\
\text { platelet counts every 10-15 minutes }\end{array}$ \\
\hline \multicolumn{2}{|c|}{$\begin{array}{l}\text { Give oxygen } \\
\text { If significant bleeding occurs give platelets (depends on the amount of } \\
\text { bleeding) } \\
\text { Correct electrolyte and metabolic abnormalities }\end{array}$} \\
\hline
\end{tabular}

infections may be aggravated. If the temperature still remains high despite administration of paracetamol, tepid sponging is recommended. ${ }^{136}$

A soft, balanced, and nutritious diet is recommended changing to oral rehydration fluids if a soft diet is refused. An antiemetic such as domperidone may be used to treat vomiting. A gastric mucosal protective agent such as cimetidine may be given to patients with evidence of gastrointestinal bleeding or at risk of such bleeding due to very low platelet counts. During the febrile phase, administration of intravenous fluids is usually not necessary, except for patients with severe vomiting or dehydration. Platelet counts and packed cell volume should be done daily beginning on the third day of fever, as the patient is likely to progress into the plasma leakage phase during this time. Platelet counts $<100 \times 10^{9} / 1$ and rises in packed cell volume of $>20 \%$, reflect significant plasma loss. ${ }^{136}$

Since dengue fever is usually a mild self limiting disease, most patients can be managed at home. However, admission to hospital is needed if patients show any sinister features such as bleeding, clinical deterioration with defervescence, changes in the level of consciousness, or laboratory evidence of DHF. Patients who cannot eat or drink due to weakness may also be admitted because of the risk of dehydration. Furthermore, those at high risk of developing severe DHF (age $<$ l year, overweight/obese, massive bleeding, changes in level of consciousness, presence of underlying disease, for example, heart disease, anaemia) should be monitored very carefully.

\section{Management of DHF}

According to the severity of clinical symptoms, DHF is divided into four grades (box 4). Adequate fluid administration, regular assessment of fluid and electrolyte balance, and 
monitoring for development of complications is vital. Vital signs should be monitored every 1-2 hours to detect early progression to shock. The packed cell volume should ideally be monitored every 4-6 hours (or at least twice a day if this is not possible). The rate of fluid administration depends on body weight and degree of plasma leakage (box 7). ${ }^{137}$ This rate should be adjusted by frequent assessment of vital signs, urine output, and packed cell volume. Liver enzymes should be measured, as acute liver failure and hepatic encephalopathy are known complications.

Controversy exists regarding the type of fluid to be used for fluid replacement in DHF. Although the WHO recommends using crystalloid solutions, some studies suggest that initial resuscitation using colloids (dextran 70 or $3 \%$ gelatin) restores the cardiac index and pulse pressure and normalises the packed cell volume sooner than crystalloid solutions. ${ }^{138}$ Despite this there seems to be no overall difference in the recovery times or the subsequent need for fluids.

Platelet transfusions may be given to patients that develop serious haemorrhagic manifestations or have very low platelet counts, although the exact platelet count at which platelet transfusions should be given is debatable. Transfusion requirements correlate with the occurrence of bleeding in the gastrointestinal tract, but not with platelet counts. ${ }^{139}$ A significant reduction in active bleeding is observed following platelet transfusions. The degree of elevation of circulating platelets tends to vary inversely with the degree of shock and directly with the amount of platelets infused. Furthermore, the survival of transfused platelets is very short in cases with dengue shock syndrome. ${ }^{140}$

The critical phase usually lasts for 24-48 hours and is then followed by a convalescent phase. Intravenous fluid therapy could usually be stopped when the packed cell volume falls to 0.40 . It is important to identify the end of the leakage phase, as otherwise overzealous fluid administration could lead to respiratory distress secondary to massive pleural effusions/ ascites or pulmonary oedema.

\section{Management of dengue shock syndrome}

The management of dengue shock syndrome is a medical emergency needing prompt and adequate fluid replacement. The patient should be kept flat and oxygen administered. Vital signs (blood pressure, pulse rate and pressure, capillary refill time) should be monitored every 10-15 minutes. Oxygen saturation may be monitored by a pulse oxymeter. Intravenous fluid should be infused using a wide bore cannula, with another wide bore cannula sited on the opposite arm/leg. Blood should be sent for grouping and cross match, urea and electrolytes, full blood count, and liver function tests. Electrolyte abnormalities, hypoglycaemia, and metabolic acidosis are commonly seen during refractory shock and need to be looked for and corrected. Disseminated intravascular coagulation is usually present and may lead to worsening of shock or massive bleeding. Hence, prothrombin time and partial thromboplastin time should be measured

Box 7: Maintenance fluid requirements in DHF (calculated according to the Halliday and Segar formula)

- $<10 \mathrm{~kg}$ body weight: $100 \mathrm{ml} / \mathrm{kg}$.

- 10-20 kg body weight: $1000 \mathrm{ml}+50 \mathrm{ml}$ for each $\mathrm{kg}$ in excess of $10 \mathrm{~kg}$.

- $>20 \mathrm{~kg}$ body weight: $1500 \mathrm{ml}+20 \mathrm{ml}$ for each $\mathrm{kg}$ in excess of $20 \mathrm{~kg}$. and fresh frozen plasma, platelet concentrate, or cryoprecipitate given if there is evidence of disseminated intravascular coagulation.

Ideal fluid management includes both cystalloids and colloids (including albumin). Cystalloids are given as rapid boluses, with as many as two to three boluses needed in profound shock. ${ }^{141}$ A double blind randomised controlled trial compared four intravenous fluid regimens for acute resuscitation in 50 children with dengue shock syndrome. Colloids (dextran 70 or the protein digest gelafundin 35000 ) were found to restore cardiac index and blood pressure and normalise packed cell volume more rapidly compared with crystalloids (Ringer's lactate or $0.9 \%$ weight/volume saline). Moreover, dextran 70 produced the most rapid normalisation of the packed cell volume and cardiac index, with no major adverse effects, and hence may be the preferred solution for acute resuscitation in dengue shock syndrome. ${ }^{142}$

Vital signs should be frequently recorded (every 1015 minutes), and the packed cell volume regularly measured. Patients who develop disseminated intravascular coagulation need supportive therapy with blood products (blood, fresh frozen plasma, and platelet transfusions). Polyserositis (manifesting as pleural effusions or ascitis) are common, but drainage procedures should be avoided as they may lead to severe haemorrhage or sudden circulatory collapse. ${ }^{141}$ If shock still persists despite adequate fluid replacement, internal bleeding or myocarditis needs to be considered. Abnormalities in the electrocardiogram or cardiac enzymes support a diagnosis of myocarditis, and should be treated with inotrophes in an intensive care setting. Fresh whole blood may be needed for the treatment of internal bleeding.

Patients may be discharged from hospital once they enter the convalescent phase and have a normal appetite. They do not need to be in hospital until platelet counts return to normal (may take as long as 2-3 weeks). They could be safely discharged once platelet counts begin to rise and are over $50 \times 10^{9} /$. Patients who develop massive pleural effusions or ascites may take longer to recover and may be kept in for observation.

\section{PREVENTION AND CONTROL OF DHF}

Since there is no effective vaccine against dengue, the prevention and control of dengue infections depends largely on preventing man-vector contact. Numerous strategies have been adopted and include: environmental control, biological control, chemical control, and active case surveillance. While each of these methods have some effect, successful control programmes should incorporate all appropriate methods and also foster a strong partnership between the different dengue control agencies and the community. The dengue control programmes in the South East Asian and South Asian regions have been generally unsuccessful, largely because they have relied solely on insecticide spraying. ${ }^{2}$

\section{Environmental control methods}

These include: reducing vector breeding sites, solid waste management, modification of man made breeding sites, and improvements in house design. Public education programmes play a vital part if they are to be effective. ${ }^{143}$

Personal protection is important in preventing man-vector contact. Sufficiently thick and loose fitting clothes reduce contact with the mosquitoes, but may not be the most practical clothes to wear in hot tropical climates. Other measures such as using household insecticidal products (mosquito mats and liquid vaporisers) or mosquito repellents may also be effective. Naturally occurring repellents (citronella oil, lemon grass) or chemical repellents (DEET) are available. However, unlike in the control of malaria, insecticide treated mosquito nets have limited utility in 
dengue control programmes as the vector is chiefly a day biting mosquito.

\section{Biological control of the vector}

Biological control methods are targeted against the larval stages of the dengue vector. They include the use of larvivorous fish such as Gambusia affinis and Poecilia reticulate, endotoxin producing bacteria (Bacillus thuringiensis serotype H-14 and Bacillus sphaericus are currently used), and copepod crustaceans. Bacillus thuringiensis serotype $\mathrm{H}-14$ is more effective against $A$ aegypt $i$ with very low levels of mammalian toxicity, and has therefore been accepted for use in household containers storing water. ${ }^{2}$ The use of mesocyclops (a copepod crustacean) in the Northern Province of Vietnam led to the eradication of the vector in a many areas. ${ }^{144}$ They are most suitable for use in large containers (wells or concrete tanks) that are not cleaned regularly, as frequent cleaning leads to depletion of nutrients required by them. However, mainly due to their high cost, most of these methods have been restricted to small scale field operations. ${ }^{2}$

\section{Chemical control}

This includes the application of larvicidal insecticides or space spraying. Space spraying is more widely used as larvicidal insecticides cost more. Insecticides used for treating containers that hold water includes Temephos $1 \%$ sand granules and insect growth regulators. Regular monitoring of resistance patterns is essential as resistance to Temephos has been reported among some aedes mosquito species in the South East Asian Region. ${ }^{2}$ Insect growth regulators interfere with the development of the immature forms of the mosquito and have extremely low mammalian toxicity.

Space spraying may be applied as thermal fogs or as ultra low volume sprays. Although both methods are equally effective in killing adult mosquitoes, thermal fogging tends to be used more widely. ${ }^{145}$ Although insecticides such as malathion $4 \%$, fenitrothion $1 \%$, or pirimiphos-methyl have proved to be very effective in many control programmes, mosquito vectors develop different patterns of resistance to them. ${ }^{145-147}$

Ultra low volume applied bifenthrin, which has both adulticidal and larvicidal activities, was originally shown to be more effective than thermal fogging in the control of dengue vectors. ${ }^{148}$ Subsequent contradictory reports suggest ultra low volume spraying have no effect on the oviposition of $A$ aegypti mosquitoes, possibly because very low amounts of the aerosol reach the primary resting sites of the vector. ${ }^{30} 149$

\section{Current status of the dengue vaccine}

Much research has been carried out to develop a dengue vaccine that is safe and immunogenic against all four serotypes. Although many of the vaccines developed so far (live attenuated, chimeric, DNA, and subunit vaccines) show promising results, none are sufficiently immunogenic for routine use.

A live attenuated tetravalent vaccine was developed by serial passage of wild type viruses in primary dog kidney cells or other cell types. ${ }^{150} \mathrm{~A}$ randomised, double blind placebo controlled study showed all tetravalent vaccine recipients to have DEN-3 viraemia, and subsequently develop DEN-3 neutralising antibodies. Furthermore, all monovalent DEN-2, DEN-3, and DEN-4, and $60 \%$ of DEN-1 vaccine recipients developed neutralising and/or IgM antibodies. ${ }^{151}$ When seven formulations of tetravalent live attenuated dengue vaccine were evaluated, $58 \%$ of recipients seroconverted (neutralising antibody titre $\geqslant 1: 10$ ) to three or more serotypes after the first dose, increasing to $76 \%$ after the second dose. ${ }^{152}$ Both monovalent DEN-2 and the tetravalent vaccines show T-cell responses against all dengue serotypes. ${ }^{153}$ However, proliferation responses are higher to DEN-1 and DEN-3 than to
DEN-2 and DEN-4, whereas cytotoxic T-lymphocyte responses are higher to DEN-2 and DEN-3 than to DEN-1. ${ }^{154}$

Infectious clone technology has also been exploited for development of a dengue vaccine. A chimeric YF-dengue type 2 vaccine was prepared, using recombinant cDNA of a YF vaccine strain as backbone, to which pre-membrane and envelope genes of DEN-2 were inserted. ${ }^{155}$ Vaccine studies in monkeys have shown promising results, and currently chimeric vaccines encoding genes of the other three dengue serotypes have been constructed and are undergoing evaluation in animal models. ${ }^{150}$

The use of DNA based vaccines is another novel and promising immunisation approach. A candidate DNA vaccine expressing DEN-1 pre-membrane and envelope proteins was shown to be immunogenic in both mice and monkeys. ${ }^{150}$ To improve immunogenicity, a DEN-2 candidate vaccine containing pre-membrane and envelope genes in which transmembrane and cytoplasmic regions of envelope genes were replaced by lysosome associated membrane protein has been constructed. Mice immunised with this modified vaccine showed significantly higher levels of neutralising antibodies than the previous vaccine. ${ }^{155}$

Recombinant proteins containing the B domains of dengue virus serotypes 1-4 were fused to the maltose binding protein of Escherichia coli and evaluated in mice as a single or tetravalent vaccine. Neutralising antibody titres to each individual serotype were significantly greater than any cross reactive neutralising titre induced by the monovalent vaccines. Thus the tetravalent DEN recombinant subunit vaccine produces specific neutralising antibodies to all four dengue serotypes. ${ }^{156}$

\section{Authors' affiliations}

G N Malavige, S Fernando, Department of Microbiology, Faculty of Medical Sciences, University of Jayawardenapura, Sri Lanka

D J Fernando, Department of Medicine, University of Jayawardenapura, Sri Lanka and Department of Endocrinology, Kings Mill Hospital, Nottingham, UK

S L Seneviratne, Department of Clinical Immunology, Queen's Medical Centre, University Hospital, Nottingham, UK

\section{REFERENCES}

1 Pinheiro FP, Corber SJ. Global situation of dengue and dengue haemorrhagic fever and its emergence in the Americas. World Health Stat $Q$ 1997;50:161-8.

2 World Health Organisation. Prevention and control of dengue and dengue haemorrhagic fever: comprehensive guidelines. WHO Regional publication, SEARO, No 29, 1999.

3 Halstead SB. Is there an inapparent dengue explosion? Lancet 1999;353:1100-1

4 Nimmannitya S. Dengue haemorrhagic fever: current issues and future research. Asian-Oceanian Journal of Paediatrics and Child Health 2002; 1:1-21.

5 King CC, Wu YC, Chao DY, et al. Major epidemics of dengue in Taiwan in 1981-2000: related to intensive virus activities in Asia. Dengue Bulletin 2000;24:1-10.

6 Endy TP, Nisalak A, Chunsuttiwat S, et al. Spatial and temporal circulation of dengue virus serotypes: a prospective study of primary school children in Kamphaeng Phet, Thailand. Am J Epidemiol 2002;156:52-9.

7 Messer WB, Gubler DJ, Harris E, et al. Emergence and global spread of a dengue serotype 3, subtype III virus. Emerg Infect Dis 2003;9:800-9.

8 Guzman MG, Kouri G. Dengue: an update. Lancet Infect Dis 2002;2:33-42.

9 Rico-Hesse R. Microevolution and virulence of dengue viruses. Adv Virus Res 2003:59:315-41.

10 Sukri NC, Laras K, Wandra T, et al. Transmission of epidemic dengue hemorrhagic fever in easternmost Indonesia. Am J Trop Med Hyg 2003;68:529-35.

11 Nisalak A, Endy TP, Nimmanitya S, et al. Serotype-specific dengue virus circulation and dengue disease in Bangkok, Thailand from 1973 to 1999. Am J Trop Med Hyg 2003;68:191-202.

12 Chareonsook O, Foy HM, Teeraratkul A, et al. Changing epidemiology of dengue hemorrhagic fever in Thailand. Epidemiol Infect 1999;122:161-6.

13 Ha DQ, Tien NT, Huong VT, et al. Dengue epidemic in Southern Vietnam, 1998. Emerg Infect Dis 2000;6:422-5.

14 Anonymous. Dengue in the WHO Western Pacific Region. Weekly Epidemiological Record 1998;72:273-80. 
15 Munasinghe DR, Amarasekera PJ, Fernando CF. An epidemic of dengue-like fever in Ceylon (chikungunya) - a clinical and haematological study. Ceylon Med J 1966;11:129-42.

16 Messer WB, Vitarana UT, Sivananthan K, et al. Epidemiology of dengue in Sri Lanka before and after the emergence of epidemic dengue hemorrhagic fever. Am J Trop Med Hyg 2002;66:765-73.

17 Dar L, Broor S, Sengupta S, et al. First major outbreak of dengue hemorrhagic fever in Delhi, India. Emerg Infect Dis 1999;5:589-90.

18 Qiu FX, Gubler DJ, Liu JC, et al. Dengue in China: a clinical review. Bull World Health Organ 1993;71:349-59.

19 Fan WF, Yu SR, Cosgriff TM. The reemergence of dengue in China. Rev Infect Dis 1989;1 1 (suppl 4):S847-53.

20 Tadano M, Okuno Y, Fukunaga T, et al. Retrospective serological studies on dengue epidemics in Osaka and Okinawa. Biken J 1983;26:165-7.

21 Guzman MG, Kouri G, Vazquez S, et al. DHF epidemics in Cuba, 1981 and 1997: some interesting observations. Dengue Bulletin 1999;23:39-43.

22 Guzman Tirado MG, Kouri Flores G, Bravo Gonzalez JR. Emergence of dengue hemorrhagic fever in the Americas. Reemergence of dengue. Rev Cubana Med Trop 1999;51:5-13.

23 Guzman MG, Kouri G. Dengue and dengue hemorrhagic fever in the Americas: lessons and challenges. J Clin Virol 2003;27:1-13.

24 Halstead SB, Streit TG, Lafontant JG, et al. Haiti: absence of dengue hemorrhagic fever despite hyperendemic dengue virus transmission. Am J Trop Med Hyg 2001;65:180-3.

25 Guzman MG, Kouri G. Advances in dengue diagnosis. Clin Diagn Lab Immunol 1996;3:621-7.

26 Young PR, Hilditch PA, Bletchly $C$, et al. An antigen capture enzyme-linked immunosorbent assay reveals high levels of the dengue virus protein NS1 in the sera of infected patients. J Clin Microbiol 2000;38:1053-7.

27 Libraty DH, Young PR, Pickering D, et al. High circulating levels of the dengue virus nonstructural protein NS1 early in dengue illness correlate with the development of dengue hemorrhagic fever. $J$ Infect Dis 2002;186:1165-8 (Epub 16 September 2002).

28 Cardosa MJ, Wang SM, Sum MS, et al. Antibodies against prM protein distinguish between previous infection with dengue and Japanese encephalitis viruses. BMC Microbiol 2002;2:9 (Epub 5 May2002)

29 Thavara U, Tawatsin A, Chansang C, et al. Larval occurrence, oviposition behavior and biting activity of potential mosquito vectors of dengue on Samui Island, Thailand. J Vector Ecol 2001;26:172-80.

30 Perich MJ, Davila G, Turner A, et al. Behavior of resting Aedes aegypti (culicidae: diptera) and its relation to ultra-low volume adulticide efficacy in Panama City, Panama. J Med Entomol 2000;37:541-6.

31 Vezzani D, Schweigmann N. Suitability of containers from different sources as breeding sites of Aedes aegypti (L) in a cemetery of Buenos Aires City, Argentina. Mem Inst Oswaldo Cruz 2002;97:789-92.

32 Thu HM, Aye KM, Thein S. The effect of temperature and humidity on dengue virus propagation in Aedes aegypti mosquitos. Southeast Asian J Trop Med Public Health 1998;29:280-4

33 Watts DM, Burke DS, Harrison BA, et al. Effect of temperature on the vector efficiency of Aedes aegypti for dengue 2 virus. Am J Trop Med Hyg 1987;36:143-52.

34 Platt KB, Linthicum KJ, Myint KS, et al. Impact of dengue virus infection on feeding behavior of Aedes aegypti. Am J Trop Med Hyg 1997;57:119-25.

35 Joshi V, Mourya DT, Sharma RC. Persistence of dengue- 3 virus through transovarial transmission passage in successive generations of Aedes aegypti mosquitoes. Am J Trop Med Hyg 2002;67:158-61.

36 Rosen L. Sexual transmission of dengue viruses by Aedes albopictus. Am J Trop Med Hyg 1987;37:398-402.

37 Ahmed FU, Mahmood CB, Sharma JD, et al. Dengue fever and dengue haemorrhagic fever in chidren the 2000 out break in Chittatong, Bangladesh. Dengue Bulletin 2001;25:33-9.

38 Narayanan M, Aravind MA, Thilothammal N, et al. Dengue fever epidemic in Chennai-a study of clinical profile and outcome. Indian Pediatr 2002;39:1027-33.

39 Hongsiriwon S. Dengue hemorrhagic fever in infants. Southeast Asian J Trop Med Public Health 2002;33:49-55.

40 Pancharoen C, Mekmullica J, Thisyakorn U. Primary dengue infection: what are the clinical distinctions from secondary infection? Southeast Asian J Trop Med Public Health 2001;32:476-80.

41 Kabra SK, Jain Y, Pandey RM, et al. Dengue haemorrhagic fever in children in the 1996 Delhi epidemic. Trans R Soc Trop Med Hyg 1999;93:294-8.

42 Swasdivorn S, Vibulvatanakit S, Sasavatpakde RN, et al. Efficicacy of clinical diagnosis pod dengue fever in pediatric age groups as determined by the WHO case definition 1997 in Thailand. Dengue Bulletin 2001;25:56-64.

43 Kalayanarooj S, Nimmannitya S, Suntayakorn S, et al. Can doctors make an accurate diagnosis of dengue infections at an early stage? Dengue Bulletin 1999;23:1-9.

44 Martinez E, Guzman MG, Valdes M, et al. Dengue fever and hemorrhagic dengue in infants with a primary infection. Rev Cubana Med Trop 1993;45:97-101.

45 Halstead SB, Lan NT, Myint TT, et al. Dengue hemorrhagic fever in infants: research opportunities ignored. Emerg Infect Dis 2002;8:1474-9.

46 Mendez A, Gonzalez G. Dengue haemorrhagic fever in children: ten years of clinical experience. Biomedica 2003;23:180-93.

47 Srivastava VK, Suri S, Bhasin A, et al. An epidemic of dengue haemorrhagic fever and dengue shock syndrome in Delhi: a clinical study. Ann Trop Paediatr 1990;10:329-34.

48 Anuradha S, Singh NP, Rizvi SN, et al. The 1996 outbreak of dengue hemorrhagic fever in Delhi, India. Southeast Asian J Trop Med Public Health 1998;29:503-6.
49 Richards AL, Bagus R, Baso SM, et al. The first reported outbreak of dengue hemorrhagic fever in Irian Jaya, Indonesia. Am J Trop Med Hyg 1997;57:49-55.

50 Aggarwal A, Chandra J, Aneja S, et al. An epidemic of dengue hemorrhagic fever and dengue shock syndrome in children in Delhi. Indian Pediatr 1998;35:727-32.

51 Guzman MG, Alvarez M, Rodriguez R, et al. Fatal dengue hemorrhagic fever in Cuba, 1997. Int J Infect Dis 1999;3:130-5.

52 Lucus GN, Karunatilaka DH, Wijesuriya AP, et al. Guidelines for management of dengue haemorrhagic fever (DHF). Sri Lanka: Sri Lankan College of Paediatricians, 2003.

53 Kalayanarooj S, Chansiriwongs V, Nimmannitya S. Dengue patients at the Children's Hospital, Bangkok: 1995-1999. Review. Dengue Bulletin 2002;26:33-43

54 Kabra SK, Jain Y, Singhal T, et al. Dengue hemorrhagic fever: clinical manifestations and management. Indian J Pediatr 1999;66:93-101.

55 Wali JP, Biswas A, Handa R, et al. Dengue haemorrhagic fever in adults: a prospective study of 110 cases. Trop Doct 1999:29:27-30.

56 Guzman MG, Kouri GP, Bravo J, et al. Dengue haemorrhagic fever in Cuba. II. Clinical investigations. Trans R Soc Trop Med Hyg 1984;78:239-41.

57 Kabra SK, Jain Y, Pandey RM, et al. Dengue haemorrhagic fever in children in the 1996 Delhi epidemic. Trans R Soc Trop Med Hyg 1999;93:294-8.

58 Agarwal R, Kapoor S, Nagar R, et al. A clinical study of the patients with dengue hemorrhagic fever during the epidemic of 1996 at Lucknow, India. Southeast Asian J Trop Med Public Health 1999;30:735-40.

59 Kalayanarooi S, Vaughn DW, Nimmannitya S, et al. Early clinical and laboratory indicators of acute dengue illness. J Infect Dis 1997;176:313-21.

60 Huang YH, Liu CC, Wang ST, et al. Activation of coagulation and fibrinolysis during dengue virus infection. Med Virol 2001;63:247-51

61 Van Gorp EC, Suharti C, Mairuhu AT, et al. Changes in the plasma lipid profile as a potential predictor of clinical outcome in dengue hemorrhagic fever. Clin Infect Dis 2002;34:1150-3.

62 Pancharoen C, Rungsarannont A, Thisyakorn U. Hepatic dysfunction in dengue patients with various severity. J Med Assoc Thai 2002;85(suppl 1):S298-301.

63 Huerre MR, Lan NT, Marianneau P, et al. Liver histopathology and biological correlates in five cases of fatal dengue fever in Vietnamese children. Virchows Arch 2001;438:107-15.

64 Mohan B, Patwari AK, Anand VK. Hepatic dysfunction in childhood dengue infection. J Trop Pediatr 2000;46:40-3.

65 Kalayanarooi S, Nimmannitya S. Clinical and Labarotory presentations of of Dengue patients with diiferent serotypes. Dengue Bulletin 2000;24:53-9.

66 Nguyen TL, Nguyen TH, Tieu NT. The impact of dengue haemorrhagic fever on liver function. Res Virol 1997; 148:273-7.

67 Cam BV, Fonsmark L, Hue NB, et al. Prospective case-control study of encephalopathy in children with dengue hemorrhagic fever. Am J Trop Med Hyg 2001;65:848-51.

68 Lum LC, Lam SK, Choy YS, et al. Dengue encephalitis: a true entity? Am J Trop Med Hyg 1996;54:256-9.

69 Chaturvedi UC, Dhawan R, Khanna M, et al. Breakdown of the blood-brain barrier during dengue virus infection of mice. J Gen Virol 1991;72(pt 4):859-66.

70 Wali JP, Biswas A, Chandra S, et al. Cardiac involvement in dengue haemorrhagic fever. Int J Cardiol 1998;64:31-6.

71 Kabra SK, Juneja R, Madhulika, et al. Myocardial dysfunction in children with dengue haemorrhagic fever. Natl Med J India 1998;11:59-61.

72 King CA, Marshall JS, Alshurafa H, et al. Release of vasoactive cytokines by antibody-enhanced dengue virus infection of a human mast cell/basophil line. J Virol 2000;74:7146-50.

73 Ling Jun Ho, Wang JJ, Shaio MF, et al. Infection of human dendritic cells by dengue virus causes cell maturation and cytokine production. J Immunol 2001; 166:1499-506.

74 Huang YH, Lei HY, Liu HS, et al. Dengue virus infects human endothelial cells and induces IL-6 and IL-8 production. Am J Trop Med Hyg 2000;63:71-5.

75 Libraty DH, Young PR, Pickering D, et al. High circulating levels of the dengue virus nonstructural protein NS1 early in dengue illness correlate with the development of dengue hemorrhagic fever. J Infect Dis 2002; 186:1165-8

76 Littaua R, Kurane I, Ennis FA. Human IgG Fc receptor II mediates antibodydependent enhancement of dengue virus infection. J Immunol 1990; 144:3183-6.

77 Halstead SB. Pathogenesis of dengue: challenges to molecular biology. Science 1988;239:476-81

78 Yang KD, Yeh WT, Yang MY, et al. Antibody-dependent enhancement of heterotypic dengue infections involved in suppression of IFNgamma production. J Med Virol 2001;63:150-7.

79 Lin CF, Lei HY, Shiau AL, et al. Endothelial cell apoptosis induced by antibodies against dengue virus nonstructural protein 1 via production of nitric oxide. J Immunol 2002; 169:657-64.

80 Koraka P, Suharti C, Setiati TE, et al. Kinetics of dengue virus-specific serum immunoglobulin classes and subclasses correlate with clinical outcome of infection. J Clin Microbiol 2001;39:4332-8.

81 Thein S, Aaskov J, Myint TT, et al. Changes in levels of anti-dengue virus lgG subclasses in patients with disease of varying severity. J Med Virol 1993;40:102-6.

82 Koraka P, Murgue B, Deparis X, et al. Elevated levels of total and dengue virus-specific immunoglobulin $E$ in patients with varying disease severity. J Med Virol 2003;70:91-8.

83 Miguez-Burbano MJ, Jaramillo CA, Palmer CJ, et al. Total immunoglobulin E levels and dengue infection on San Andres Island, Colombia. Clin Diagn Lab Immunol 1999;6:624-6. 
84 Chaturvedi UC, Elbishbishi EA, Agarwal R, et al. Sequential production of cytokines by dengue virus-infected human peripheral blood leukocyte cultures. J Med Virol 1999;59:335-40

85 Hathirat $P$, Isarangkura $P$, Srichaikul T, et al. Abnormal hemostasis in dengue hemorrhagic fever. Southeast Asian J Trop Med Public Health 1993;24(suppl 1):80-5.

86 Lin CF, Lei HY, Liu CC, et al. Generation of IgM anti-platelet autoantibody in dengue patients. J Med Virol 2001;63:143-9.

87 Wang S, He R, Patarapotikul J, et al. Antibody-enhanced binding of dengue2 virus to human platelets. Virology 1995;213:254-7.

88 Boonpucknavig S, Vuttiviroj O, Bunnag C, et al. Demonstration of dengue antibody complexes on the surface of platelets from patients with dengue hemorrhagic fever. Am J Trop Med Hyg 1979;28:881-4.

89 Gilbreath MJ, Pavanand K, MacDermott RP, et al. Cold-reactive immunoglobulin $M$ antilymphocyte antibodies directed against $B$ cells in Thai children with dengue hemorrhagic fever. J Clin Microbiol 1983; 17:672-6.

90 Mustafa AS, Elbishbishi EA, Agarwal R, et al. Elevated levels of interleukin13 and IL-18 in patients with dengue hemorrhagic fever. FEMS Immunol Med Microbiol 2001;30:229-33.

91 Vitarana T, de Silva H, Withana N, et al. Elevated tumour necrosis factor in dengue fever and dengue haemorrhagic fever. Ceylon Med J 1991;36:63-5.

92 Christine A King, Marshall JS, Alshurafa $\mathrm{H}$, et al. Release of vasoactive cytokines by antibody-enhanced dengue virus infection of a human mast cell/basophil line. J Virol 2000;74:71 46-50.

93 Chaturvedi UC, Elbishbishi EA, Agarwal R, et al. Cytotoxic factorautoantibodies: possible role in the pathogenesis of dengue haemorrhagic fever. FEMS Immunol Med Microbiol 2001;30:181-6.

94 Juffrie M, Meer GM, Hack CE, et al. Inflammatory mediators in dengue virus infection in children: interleukin- 6 and its relation to $C$-reactive protein and secretory phospholipase A2. Am J Trop Med Hyg 2001;65:70-5.

95 Raghupathy R, Chaturvedi UC, Al-Sayer H, et al. Elevated levels of IL-8 in dengue hemorrhagic fever. J Med Virol 1998;56:280-5

96 Juffrie M, van Der Meer GM, Hack CE, et al. Inflammatory mediators in dengue virus infection in children: interleukin- 8 and its relationship to neutrophil degranulation. Infect Immun 2000;68:702-7.

97 Kurane I, Meager A, Ennis FA. Induction of interferon alpha and gamma from human lymphocytes by dengue virus-infected cells. J Gen Virol 1986;67(pt 8):1653-61.

98 Kurane I, Ennis FA. Induction of interferon alpha from human lymphocytes by autologous, dengue virus-infected monocytes. J Exp Med 1987; 166:999-1010.

99 Kurane I, Innis BL, Nimmannitya S, et al. High levels of interferon alpha in the sera of children with dengue virus infection. Am J Trop Med Hyg 1993;48:222-9.

100 Green S, Vaughn DW, Kalayanarooj S, et al. Early immune activation in acute dengue illness is related to development of plasma leakage and disease severity. J Infect Dis 1999;179:755-62.

101 Libraty DH, Pichyangkul S, Ajariyakhajorn C, et al. Human dendritic cells are activated by dengue virus infection: enhancement by gamma interferon and implications for disease pathogenesis. J Virol 2001;75:3501-8.

102 Kontny U, Kurane I, Ennis FA. Gamma interferon augments Fc gamma receptor-mediated dengue virus infection of human monocytic cells. J Virol 1988;62:3928-33

103 Ho L, Wang JJ, Shaio MF, et al. Infection of human dendritic cells by dengue virus causes cell maturation and cytokine production. J Immunol 2001; 166:1499-506.

104 Azeredo EL, Zagne SM, Santiago MA, et al. Characterisation of lymphocyte response and cytokine patterns in patients with dengue fever. Immunobiology 2001;204:494-507.

105 Mentor NA, Kurane I. Dengue virus infection of human T lymphocytes. Acta Virol 1997;41:175-6.

106 Sierra B, Garcia G, Perez AB, et al. Long-term memory cellular immune response to dengue virus after a natural primary infection. Int $J$ Infect Dis 2002;6:125-8.

107 Kurane I, Innis BL, Nimmannitya S, et al. Human immune responses to dengue viruses. Southeast Asian J Trop Med Public Health 1990;21:658-62.

108 Mathew A, Kurane I, Rothman AL, et al. Dominant recognition by human CD8+ cytotoxic T lymphocytes of dengue virus nonstructural proteins NS3 and NS1.2a. J Clin Invest 1996;98:1684-91.

109 Kurane I, Brinton MA, Samson AL, et al. Dengue virus-specific, human CD4+ CD8- cytotoxic T-cell clones: multiple patterns of virus cross-reactivity recognized by NS3-specific T-cell clones. J Virol 1991;65:1823-8.

110 Gagnon SJ, Ennis FA, Rothman AL. Bystander target cell lysis and cytokine production by dengue virus-specific human CD4(+) cytotoxic T-lymphocyte clones. J Virol 1999;73:3623-9.

111 Kurane I, Innis BL, Nisalak A, et al. Human T cell responses to dengue virus antigens. Proliferative responses and interferon gamma production. J Clin Invest 1989:83:506-13.

112 Sarasombath S, Suvatte V, Homchampa P. Kinetics of lymphocyte subpopulations in dengue hemorrhagic fever/dengue shock syndrome. Southeast Asian J Trop Med Public Health 1988;19:649-56.

113 La Russa VF, Innis BL. Mechanisms of dengue virus-induced bone marrow suppression. Baillieres Clin Haematol 1995;8:249-70.

114 Liu CC, Huang KJ, Lin YS, et al. Transient CD4/CD8 ratio inversion and aberrant immune activation during dengue virus infection. J Med Virol 2002;68:241-52

115 Kurane I, Innis BL, Nimmannitya S, et al. Activation of T lymphocytes in dengue virus infections. High levels of soluble interleukin 2 receptor, soluble CD4, soluble CD8, interleukin 2, and interferon-gamma in sera of children with dengue. J Clin Invest 1991;88:1473-80.
116 Kurane I, Innis BL, Hoke CH Jr, et al. T cell activation in vivo by dengue virus infection. J Clin Lab Immunol 1995;46:35-40.

117 Mathew A, Kurane I, Green S, et al. Impaired T cell proliferation in acute dengue infection. J Immunol 1999;162:5609-15.

118 Guzman MG, Kouri GP, Bravo J, et al. Dengue hemorrhagic fever in Cuba, 1981: a retrospective seroepidemiologic study. Am J Trop Med Hyg 1990;42:179-84.

119 Guzman MG, Kouri G, Bravo J, et al. Effect of age on outcome of secondary dengue 2 infections. Int J Infect Dis 2002;6:1 18-24.

120 Kabra SK, Jain Y, Pandey RM, et al. Dengue haemorrhagic fever in children in the 1996 Delhi epidemic. Trans R Soc Trop Med Hyg 1999;93:294-8.

121 Thisyakorn U, Nimmannitya S. Nutritional status of children with dengue hemorrhagic fever. Clin Infect Dis 1993;16:295-7.

122 Cunha RV, Schatzmayr HG, Miagostovich MP, et al. Dengue epidemic in the State of Rio Grande do Norte, Brazil, in 1997. Trans R Soc Trop Med Hyg 1999:93:247-9.

123 Bravo JR, Guzman MG, Kouri GP. Why dengue haemorrhagic fever in Cuba? 1. Individual risk factors for dengue haemorrhagic fever/dengue shock syndrome (DHF/DSS). Trans R Soc Trop Med Hyg 1987;81:816-20.

124 Guzman MG, Kouri G, Soler M. Dengue 2 virus enhancement in asthmatic and non asthmatic individual. Mem Inst Oswaldo Cruz 1992;87:559-64.

125 Halstead SB, Streit TG, Lafontant JG, et al. Haiti: absence of dengue hemorrhagic fever despite hyperendemic dengue virus transmission. Am J Trop Med Hyg 2001;65:180-3.

126 Loke H, Bethell DB, Phuong CXT, et al. Strong HLA class I restricted responses in dengue haemorrhagic fever: a double edged sword? J Infect Dis $2001 ; 184: 1369-73$.

127 Stephens HA, Klaythong R, Sirikong M, et al. HLA-A and -B allele associations with secondary dengue virus infections correlate with disease severity and the infecting viral serotype in ethnic Thais. Tissue Antigens 2002;60:309-18.

128 Loke H, Bethell D, Phuong CX, et al. Susceptibility to dengue hemorrhagic fever in vietnam: evidence of an association with variation in the vitamin $d$ receptor and Fc gamma receptor lla genes. Am J Trop Med Hyg 2002;67:102-6.

129 Henchal EA, McCown JM, Seguin MC, et al. Rapid identification of dengue virus isolates by using monoclonal antibodies in an indirect immunofluorescence assay. Am J Trop Med Hyg 1983;32:164-9.

130 Branch SL, Levett PN. Evaluation of four methods for detection of immunoglobulin $\mathrm{M}$ antibodies to dengue virus. Clin Diagn Lab Immunol 1999:6:555-7.

131 Kuno G, Gubler DJ, Santiago de Weil NS. Antigen capture ELISA for the identification of dengue viruses. J Virol Methods 1985;12:93-103.

132 Nawa M, Ichikawa Y, Inouye S. Serotyping of dengue viruses by an enzymelinked immunosorbent assay. Jpn J Med Sci Biol 1985:38:217-21.

133 Velathanthiri N, Fernando R, Fernando S, et al. Development of a polymerase chain reaction (PCR) for the detection of dengue virus and its sero types. Abstract presented at the Sri Lanka College of Microbiologists annual sessions, 2002

134 De Paula SO, Pires Neto RJ, Correa JA, et al. The use of reverse transcription-polymerase chain reaction (RT-PCR) for the rapid detection and identification of dengue virus in an endemic region: a validation study. Trans R Soc Trop Med Hyg 2002;96:266-9.

135 Tripathi BK, Gupta B, Sinha RS, et al. Experience in adult population in dengue outbreak in Delhi. J Assoc Physicians India 1998;46:273-6.

136 Workshop on case management of dengue hemorrhagic fever, June 2002, Bangkok, Thailand.

137 Halliday MA, Segar WE. Maintenance need for water: in parenteral fluid therapy. Pediatrics 1957; 19:823.

138 Wills B. Volume replacement in dengue shock syndrome. Dengue Bulletin $2001 ; 25: 50-5$.

139 Chuansumrit A, Phimolthares V, Tardtong P, et al. Transfusion requirements in patients with dengue hemorrhagic fever. Southeast Asian J Trop Med Public Health 2000;31:10-4.

140 Isarangkura $\mathbf{P}$, Tuchinda $\mathrm{S}$. The behavior of transfused platelets in dengue hemorrhagic fever. Southeast Asian J Trop Med Public Health 1993;24(suppl 1):222-4

141 Soni A, Chugh K, Sachdev A, et al. Management of dengue fever in ICU. Indian J Pediatr 2001;68:1051-5.

142 Dung NM, Day NP, Tam DT, et al. Fluid replacement in dengue shock syndrome: a randomized, double-blind comparison of four intravenous-fluid regimens. Clin Infect Dis 1999;29:787-94.

143 Van Benthem BH, Khantikul N, Panart K, et al. Knowledge and use of prevention measures related to dengue in northern Thailand. Trop Med Int Health 2002;7:993-1000.

144 Kay BH, Nam VS, Tien TV, et al. Control of aedes vectors of dengue in three provinces of Vietnam by use of mesocyclops (copepoda) and communitybased methods validated by entomologic, clinical, and serological surveillance. Am J Trop Med Hyg 2002;66:40-8.

145 Gratz NG. Space sprays for the control of Aedes aegypti in South-East Asia and the Western Pacific. Dengue Bulletin 1999;24:80-4.

146 Huong VD, Ngoc NTB. Susceptibility of Aedes aegypti to insecticides. Dengue Bulletin 1999;23:85-8.

147 Katyal R, Tewari P, Rahman SJ, et al. Susceptibility status of immature and adult stages of Aedes aegypti against conventional insecticides in Delhi, India. Dengue Bulletin 2001;25:84-7.

148 Lee HL, Khadri MS, Chiang YF. Preliminary field evaluation of the combined adulticidal, larvicidal, and wall residual activity of ULV-applied bifenthrin against mosquitoes. J Vector Ecol 1997;22:146-9. 
149 Castle T, Amador M, Rawlins S, et al. Absence of impact of aerial malathion treatment on Aedes aegypti during a dengue outbreak in Kingston, Jamaica. Rev Panam Salud Publica 1999;5:100-5.

150 Perikov Y. Development of dengue vaccine. Dengue Bulletin 2000;24:71-76.

151 Kanesa-thasan N, Sun W, Kim-Ahn G, et al. Safety and immunogenicity of attenuated dengue virus vaccines (Aventis Pasteur) in human volunteers. Vaccine 2001;19:3179-88.

152 Sabchareon A, Lang J, Chanthavanich P, et al. Safety and immunogenicity of tetravalent live-attenuated dengue vaccines in Thai adult volunteers: role of serotype concentration, ratio, and multiple doses. Am J Trop Med Hyg 2002;66:264-72.

153 Rabablert J, Dharakul T, Yoksan S, et al. Dengue virus specific $\mathrm{T}$ cell responses to live attenuated monovalent dengue- 2 and tetravalent dengue vaccines. Asian Pac J Allergy Immunol 2000; 18:227-35

154 Rothman AL, Kanesa-thasan N, West K, et al. Induction of T lymphocyte responses to dengue virus by a candidate tetravalent live attenuated dengue virus vaccine. Vaccine 2001;19:4694-9.

155 Raviprakash K, Marques E, Ewing D, et al. Synergistic neutralizing antibody response to a dengue virus type 2 DNA vaccine by incorporation of lysosome-associated membrane protein sequences and use of plasmid expressing GM-CSF. Virology 2001;290:74-82.

156 Simmons M, Murphy GS, Kochel T, et al. Characterization of antibody responses to combinations of a dengue-2 DNA and dengue-2 recombinant subunit vaccine. Am J Trop Med Hyg 2001;65:420-6

\section{IMAGES IN MEDICINE}

\section{Tumoral calcinosis in end stage renal disease}

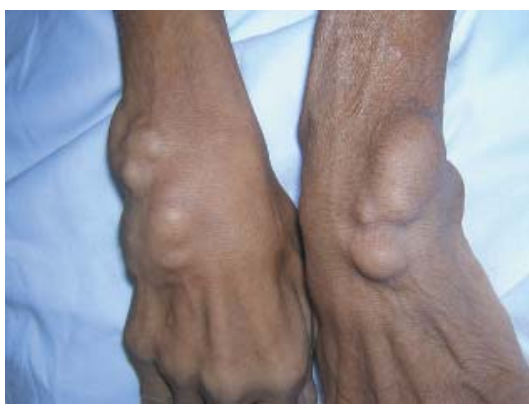

Figure 1 Nodules on patient's hands (published with patient's permission).

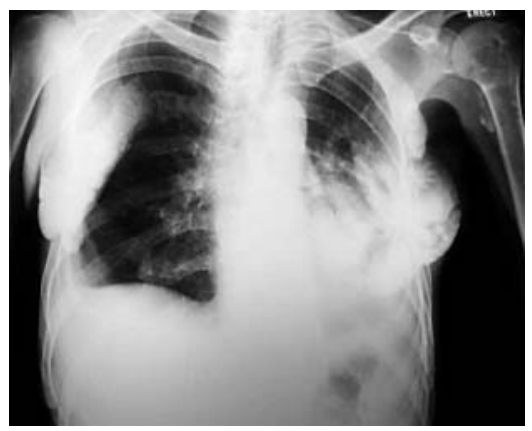

Figure 3 Chest radiograph of lesions.
$\Lambda$ 48 year old woman with end stage renal disease who had been on peritoneal dialysis since 1998 presented with multiple enlarging nodules over both hands (fig 1), especially around the wrists. They were non-tender and clinically resembled gouty tophi. The fasting serum urate concentration was normal, but serum parathyroid hormone and calciumphosphate product were raised. On examination, two relatively large subcutaneous lesions were also found on her back. They were firm in consistency and slightly lobular in appearance, similar to those found on her hands. Radiography of the lesions revealed heavy calcification (figs 2 and 3 ). Fine needle aspiration of the hand nodules and her back lumps yielded thick milky white material, which under the microscope demonstrated some granular and crystalloid eosinophilic material with significant calcification and no viable cells. The clinical presentation and histological findings were characteristic of tumoral calcinosis.

This case illustrates a rare differential diagnosis of a subcutaneous nodule or tumour-like lesion in a patient with end stage renal disease. It can mimic a soft tissue tumour, like a leiomyoma or leiomyosarcoma, or it may be confused with a gouty tophus, which is not uncommon in patients with impaired renal function. Vigorous control of the secondary hyperparathyroidism and increasing dialysis remain the mainstay of treatment. A high level of suspicion of this rare entity and a correct diagnosis can avoid unnecessary surgical intervention.

M K H Tong, Y P Siu Department of Medicine, Tuen Mun Hospital, Hong Kong, China Correspondence to: Dr Tong; khmtong@netvigator.com
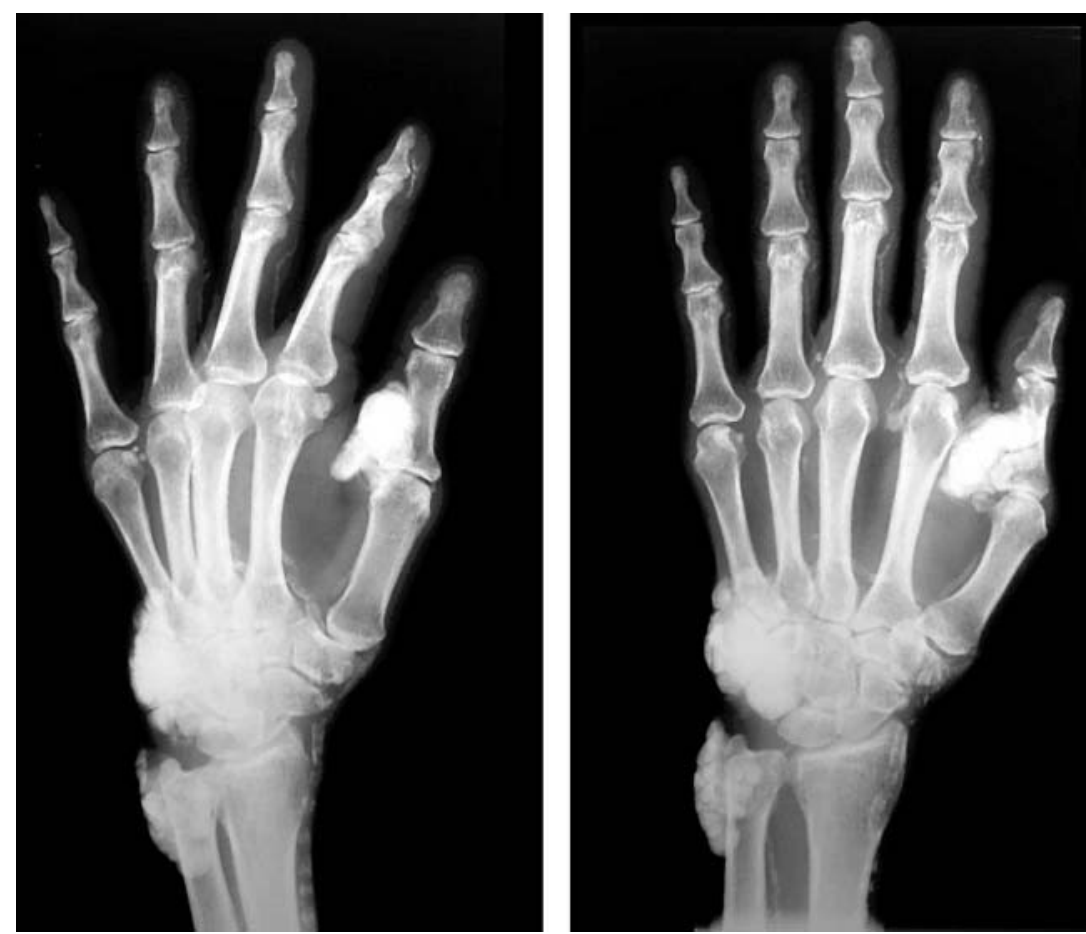

Figure 2 Radiograph of lesions on hands. 